\title{
STATE OF THE ART REVIEW OF ALTERNATIVES TO SHALLOW LAND BURIAL OF LOW LEVEL RADIOACTIVE WASTE
}

\author{
Prepared for \\ Oak Ridge National Laboratory \\ Union Carbide Corporation \\ Nuclear Division \\ Under P.O. No. 62B-13837C
}

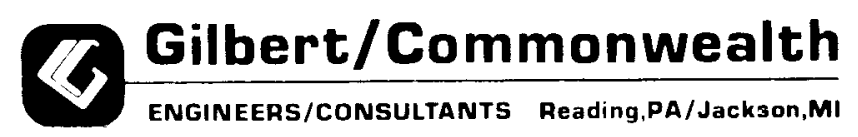

OPERATED BY

UNION CARBIDE CORPORATION FOR THE UNITED STATES DEPARTMENT OF ENERGY 


\section{Printed in the United States of America Avallable from National Technical Information Service U S Department of Commerce 5285 Port Royal Road, Sprıngfield, Virgınıa 22161 NTIS price codes-Printed Copy A06, Microfiche A01}

This report was prepared as an account of work sponsored by an agency of the United States Government Nelther the United States Government nor any agency thereof, nor any of their employees, makes any warranty express or implied or assumes any legal liability or responsibility for the accuracy, completeness, or usefulness of any information, apparatus, product, or process disclosed, or represents that its use would not infringe privately owned rights Reference herein to any specific commercial product, process, or service by trade name, trademark, manufacturer, or otherwise, does not necessarily constitute or imply its endorsement, recommendation, or favoring by the United States Government or any agency thereof The views and opinions of authors expressed herein do not necessarily state or reflect those of the United States Government or any agency thereof 


\section{DISCLAIMER}

This report was prepared as an account of work sponsored by an agency of the United States Government. Neither the United States Government nor any agency Thereof, nor any of their employees, makes any warranty, express or implied, or assumes any legal liability or responsibility for the accuracy, completeness, or usefulness of any information, apparatus, product, or process disclosed, or represents that its use would not infringe privately owned rights. Reference herein to any specific commercial product, process, or service by trade name, trademark, manufacturer, or otherwise does not necessarily constitute or imply its endorsement, recommendation, or favoring by the United States Government or any agency thereof. The views and opinions of authors expressed herein do not necessarily state or reflect those of the United States Government or any agency thereof. 


\section{DISCLAIMER}

Portions of this document may be illegible in electronic image products. Images are produced from the best available original document. 
STATE OF THE ART REVIEW OF

ALTERNATIVES TO SHALLOW

LAND BURIAL OF LOW LEVEL RADIOACTIVE WASTE

NOTICE This document contains information of a preliminary nature It is subject to revision or correction and therefore does not represent a final report.

$$
\text { Prepared by }
$$

Gilbert/Commoniwealth

Engineers/Consultants Reading, PA/Jackson, MD

Under P. 0. No. 62B-13837C

Date Published - April 1980

FOR

OAK RIDGE NATIONAL LABORATORY

Oak Ridge, Tennessee 37830

operated by

UNION CARBIDE CORPORATION

for the

DEPARTMENT OF ENERGY

Contract No. W-7405-ENG-26 
TABLE OF CONTENTS

SECTION NO.

TITLE

$\underline{\text { PAGE }}$

ABSTRACT

iii

1.0 INTRODUCTION $1-1$

2.0 IDENTIFICATION AND CATALOGING OF ALTERNATIVES 2-1

2.1 Isolation Concepts - Near Term 2-1

2.2 Isolation Concepts - Far Term 2-3

2.3 Dispersive Concepts 2-4

2.4 Conversion Concepts $2-5$

3.0 DESCRIPTION AND CURRENT STATUS OF NEAR TERM ISOLATION CONCEPTS

3.1 Upgrade of Shallow Land Burial

3-1

3.2 Intermediate Depth Burial

$3-1$

$3-10$

3.3 Disposal in Engineered Facilities

$3-17$

3.4 Disposal in Drilled Holes

$3-24$

3.5 Deep Well Injection

3.6 Disposal in Hydrofractured Strata

$3-31$

3.7 Disposal in Cavities

3.8 Seabed Disposal

$3-40$

$3-48$

$3-60$

4. 0

CONCLUSIONS

4-1

5.0

BIBLIOGRAPHY

B-1 
3-1 Mobile Gantry Crane for Intermediate Depth Waste Placement 


\begin{abstract}
A review of alternatives to shallow land burial for disposal of low level radioactive waste was conducted to assist Oak Ridge National Laboratory in developing a program for the evaluation, selection, and demonstration of the most acceptable alternatives. The alternatives, identified were categorized as follows: 1) near term isolation concepts, 2) far term isolation concepts, 3) dispersion concepts, and 4) conversion concepts. Detailed descriptions of near term isolation concepts are provided. The descriptions include: 1) method of isolation, 2) waste forms that can be accommodated, 3) advantages and disadvantages, 4) facility and equipment requirements, 5) unusual operational or maintenance requirements, 6) information/technology development requirements, and 7 ) related investigations of the concept.
\end{abstract}


SECTION 1.0

INTRODUCTION

Low level radioactive waste (LLW) as used in this report is defined as waste with radioactivity concentrations high enough that exposures in excess of those specified in Title 10 Part 20 of the Code of Federal Regulations could result if the waste is not properly isolated, but with concentrations low enough that heat generation is not a factor in its disposal. Wastes which satisfy this definition but have transuranic (TRU) contamination exceeding $10 \mathrm{nCi} / \mathrm{gm}$ or which are residues of uranium mining and milling operations are classified as TRU waste and mine and mill tailings, respectively, and are not classified as LLW.

LLW is generated by the commercial nuclear fuel cycle, defense related operations, and research and medical uses of radioisotopes. In this report, it will be assumed that the waste is in solid form unless indicated otherwise. The composition, isotopic content, and physical and chemical characteristics of the waste vary depending on its method of origin. However, for a major fraction of the LLW currently generated, the long-lived fission product radionuclides $\mathrm{Sr}-90$ and $\mathrm{Cs}-137$ (with half lives of approximately 30 years) control the isolation time required for the waste to decay to activity levels which are not considered hazardous. This results in an isolation period on the order of hundreds of years.

The current practice used in attempting to achieve this isolation period is burial of the waste in shallow trenches (see Section 3.1 for additional details). There are operating sites available for disposal of commercially generated LLW and LLW generated as a result of defense and other activities carried out by the U.S. Department of Energy (DOE).

Major problems associated with the present disposal method include:

1) leakage and overflow from burial trenches at some disposal sites; and 2) exhaustion of available disposal capacity by the end of the century at existing sites. In addition, requirements imposed on waste disposal at both the state and Federal level are expected to become increasingly restrictive. 
In order to identify, evaluate, and demonstrate potential solutions to present LLW management problems and alternatives to present practices, DOE and its contractors have formulated a comprehensive national LLW management program. The lead and associate lead contractors for carrying out this program are EG\&G Idaho and Oak Ridge National Laboratory, respectively. The major objective of the national program is to develop safe and efficient LLW disposal methods. There are a number of supporting objectives one of which is to evaluate alternatives to shallow land burial for disposal of LLW and select and demonstrate the most acceptable alternatives. This report is the result of a review performed to provide information to Oak Ridge National Laboratory for use in developing a program to carry out this objective.

The review included: 1) the results of both past and present studies of LLW disposal methods; 2) future plans for such studies; 3) published summaries and evaluations of alternative methods of waste disposal; and 4) relevant information from related activities, such as the high level waste (HLW) program. Sources consulted included the results of work performed in the United States as well as other countries with major nuclear programs. Reports issued by international nuclear organizations were also considered.

Computerized literature searches were performed using RECON and the Shallow Land Burial Data Base of ORNL's Ecological Sciences Information Center (ESIC). In addition, literature received by ESIC, but not yet included in the computer files of the Shallow Land Burial Data Base, was manually searched. The U.S. Nuclear Regulatory Commission, U.S. Geological Survey, U.S. Environmental Protection Agency, International Atomic Energy Agency, Nuclear Energy Agency, and Canadian and Japanese electric utilities were contacted to determine what, if any, work was in progress relevant to this review that had not been publicly reported.

The remaining sections of this report are organized as follows:

Section 2.0 presents the alternatives identified during the review and categorizes each alternative into one of four categories: Isolation Concepts - Near Term, Isolation Concepts - Far Term, Dispersive Concepts, and Conversion Concepts. 
Section 3.0 describes each alternative categorized as a near term isolation concept. The descriptions include: 1) method of isolation, 2) waste forms that can be accommodated, 3) advantages and disadvantages, 4) equipment and facility requirements, 5) unusual operational or maintenance requirements, 6) information/technology development requirements, and 7) related investigations of the alternative.

Section 4.0 presents conclusions reached as a result of this review.

Section 5.0 is a listing of the literature consulted during the review. 
SECTION 2.0

IDENTIFICATION AND CATALOGING OF ALTERNATIVES

A brief description of the alternatives available for LLW disposal is presented in this section. These alternatives presented are based primarily on the concepts described in References 66 and 105. Each alternative identified was cataloged as follows:

- Isolation Concepts - Near Term: alternatives for isolating wastes in an environmentally acceptable manner now available or achievable within 20 years.

- Isolation Concepts - Far Term: alternatives for isolating wastes from the biosphere that would require more than 20 years to implement because of technology development or information requirements.

- Dispersive Concepts - alternatives in which wastes are diluted to low concentrations using air, water, or soil.

- Conversion Concepts - alternatives in which wastes are converted to less hazardous forms.

Each alternative concept is explained briefly in this section. The near term isolation concepts are explained in more detail in Section 3.0.

\subsection{ISOLATION CONCEPTS - NEAR TERM}

\subsubsection{Upgrade of Shallow Land Burial Practices}

Present shallow land burial practices involve digging trenches 5 to 8 meters deep, emplacing the waste and covering it with 1 to 3 meters of fill. Techniques to cover and seal the trenches vary with custom, local climate, soil, and groundwater conditions. At all existing burial sites, an effort has been made to isolate the waste above the groundwater table. 
Techniques that could upgrade shallow land burial practices include improvements in: site selection, disposal trench capping, trench design including use of impervious liners, operational and water management, and waste forms. In situ encapsulation of the buried wastes would also be an improved shallow burial technique.

\subsubsection{Intermediate Depth Burial}

The depth of burial trenches can be increased so that the waste is covered by 10 to 20 meters of fill. At these depths, the waste will be above the water table only at relatively arid sites with depressed water tables. This alternative includes burial both above and below the water table.

\subsubsection{Disposal in Engineered Facilities}

Manmade structures can be engineered to store LLW. If they contain the waste for its hazardous life, they can be considered disposal methods. The structures can be above or below the ground surface and constructed of reinforced concrete or metal. These structures can be in the form of buildings or specialized containers.

\subsubsection{Disposal in Drilled Holes}

Established drilling techniques can provide a matrix of boreholes in an appropriate geologic medium. Waste packages would be emplaced in the holes until they reached a specified minimum distance from the surface; the holes would then be backfilled and sealed. The waste can be emplaced above or below the water table depending on the depth of the boreholes and site-specific conditions.

\subsubsection{Deep Well Injection}

Lenses of porous or fractured, subterranean material confined by impermeable geologic media lacking major faults may be suitable for deep wells. Liquid or partially solidifed wastes would be injected into the available volume in the porous or fractured material and contained by the impermeable material. 


\subsubsection{Disposal in Hydrofractured Strata}

An impermeable geologic medium can be horizontally fractured by a fluid injected radially from an isolated interval within a borehole. The fluid usually contains an agent to keep the fracture open after the fracturing fluid is drained out. Liquid wastes or slurries would be mixed with a cement grout and pumped into the fracture where they would harden.

\subsubsection{Disposal in Cavities}

Natural, conventionally mined, solution mined, and exploded cavities as well as abandoned mines may be used as repositories for wastes. Tunnels and room and pillar mines are included in this concept.

\subsubsection{Seabed Disposal}

Seabed disposal involves controlled emplacement of waste packages in the sediment or rock below the ocean floor. Techniques include trenching, drilled holes, and projectile emplacement.

\subsection{ISOLATION CONCEPTS - FAR TERM}

\subsubsection{Ice Sheet Disposal}

Continental ice sheets, such as in Greenland and Antarctica, could provide disposal sites for wastes. Containers would be placed in structures above the ice, on the ice surface, in drilled holes, or in burial sites. Anchored emplacement to restrict the waste to some minimum elevation in the ice is also possible.

\subsubsection{Extraterrestrial Disposal}

Disposal beyond the earth's atmosphere, if successful, would provide the most complete isolation of waste from earth's biosphere. Waste material would be 
packaged into a rocket or other suitable launch vehicle and transported off the earth. Several trajectories are possible:

o Stable, earth orbit about $150,000 \mathrm{~km}$ in radius

o Transport to the sun

o Solar orbit

o Solar system escape

\subsubsection{Subduction Zone Disposal}

Waste can be emplaced at locations where an oceanic plate underthrusts a continental plate (i.e., subduction zones). The concept assumes that the waste containers would be transported into the earth's lower crust by the underthrusting, which is estimated to take one to ten million years (66). This concept would be a specialized type of seabed disposal.

\subsubsection{Subcrustal Disposal}

Wastes could be injected into molten magma within the earth's upper mantle. Wastes would be injected through partially or fully cased holes from either land surfaces or ocean basins above known, shallow, magma chambers.

\subsection{DISPERSIVE CONCEPTS}

\subsubsection{Releases to the Atmosphere}

Wastes can be released at: 1) low elevations through stacks, 2) intermediate elevations from airplanes or balloons, and 3) high elevations from rockets. Gaseous wastes or those that can be converted to a vapor state are most suitable for these types of disposal.

Stacks have been used extensively to dilute and disperse wastes. Incinerator off-gases and ventilation-system air are especially suitable stack releases. 
Releases from airplanes or balloons could be from containers on these vehicles. Continuous release from a balloon via a hollow tether is another possibility.

Rocket dispersal could involve either a disposable or recoverable vehicle that releases wastes about $10 \mathrm{~km}$ or higher. Dispersal of wastes from a rocket would be over thousands of square kilometers rather than tens of square kilometers as with stack dispersal.

\subsubsection{Direct Releases to Bodies of Water}

Seas, rivers, and lakes can be used to disperse and dilute liquid wastes.

\subsubsection{Soil Mixing}

Soil has been used in the past to disperse and dilute wastes. This alternative distributes wastes into the soil by deep plowing or by using leaching ponds.

\section{$2.3 .4 \quad$ Ocean Dumping}

Packaged wastes could be dumped into the ocean without controlled emplacement. Although waste containers would be expected to remain intact for some time after dumping, this alternative is considered to be dispersive, because, eventually, the waste in the containers would be released for dilution and dispersal.

\section{$2.4 \quad$ CONVERSION CONCEPTS}

\subsubsection{Transmutation}

A nuclide could absorb or emit radiation and, thereby, be changed (transmuted) into another nuclide. For waste disposal, long lived radionuclides would be converted to shorter lived ones which would require a significantly shorter isolation period. They would be converted by bombarding them with photons or 
appropriate subatomic particles from sources such as fission reactors, fusion reactors, accelerators, or nuclear weapons tests. 
SECTION 3.0

DESCRIPTION AND CURRENT STATUS OF

NEAR TERM ISOLATION CONCEPTS

More detailed descriptions of the alternatives identified and cataloged in Section 2.0 as near term isolation concepts are presented in this section. This information is a compilation of relevant material from the literature search along with technical judgment based upon engineering, construction, operations, geology, and radioactive waste management experience. The information for each concept includes:

- Nature of isolation

- Waste forms that can be accommodated

- Advantages and disadvantages

o Equipment and facility requirements

- Unususal operational or maintenance requirements

- Geologic/environmental parameters

- Information and technology development required for implementation

- Summary of work performed by previous investigators and the status or conclusions of their investigations.

$3.1 \quad$ UPGRADE OF SHALLOW LAND BURIAL

\subsubsection{Description and Application}

In current shallow land burial practices, LLW is emplaced in trenches 60 to 260 meters long, 8 to 20 meters wide at ground surface, and 5 to 8 meters deep. The waste is covered with 1 to 3 meters of excavated fill or a combination of fill and compacted clay. The waste is buried above the water table at all existing burial sites in accordance with state or Federal regulations. However, following burial, the waste may come into contact with ground or surface waters; for example, perched water tables have developed within individual trenches, especially in burial facilities located in the humid eastern part of the country. Waste buried at commercial disposal sites is generally packaged in 210 liter U.S. Department of Transportation 
(DOT) approved steel drums. Only wastes received from offsite U.S. Department of Energy (DOE) generators must be packaged to meet DOT transportation regulations (105).

Waste isolation depends on minimal contact between the waste and ground and surface water; tectonic stability; and institutional controls to prevent inadvertent contact or exhumation by natural processes. The ion exchange capacity of the burial soil can also retard the leaching of any radionuclides to the biosphere.

Shallow land burial has been used for most LLW disposal in the U.S. since the beginning of the nuclear weapons program in the 1940s. Other countries have also used shallow land burial for LLW disposal but to a much smaller degree. A number of authors have reviewed the history, problems, and current status of the five major U.S. Department of Energy (DOE) disposal sites and the six commercial U.S. disposal sites $(8,29,51,69,81,82,90,94,95,105)$.

The improvements to shallow land burial that have been suggested include:

o Improved site selection criteria (site geomorphically stable, well suited for effective monitoring, and sufficiently simple, hydrogeologically to allow reliable prediction of residence time of radionuclides in the flow system; water table several meters below the disposed trenches; burial zone separated from fractured bedrock by strata of low permeability with sufficient thickness, and sorption properties to prevent migration of radionuclides into the fractured zone) $(29,89,90,105)$.

o Improved trench design (sloping of trench, sand underdrain, drainage ditches filled with crushed rock along bottom of trench walls, infiltration barrier such as bentonite, concrete, asphalt, or stainless steel liners above waste) $(29,67,88,89,94,105,117)$.

- Engineered containment around waste (high integrity packaging, sorption barriers) $(105,117)$. 
Prevention of voids and undermining (better waste forms through compaction or incineration of poorly compacted and biodegradable waste or improved packaging $)(29,67,88,89,105,117)$.

o Waste segregation (special treatment or alternative disposal method for organic complexing agents, long-lived waste, and waste posing special hazards $)(89,105)$.

- Improved operational practices (temporary weather shields, surface and ground water diversion, erosion protection, better definition of waste package contents and record keeping, better compatibility of waste with burial conditions, measures to discourage deep rooted plant species) (29, $67,88,89,105)$.

Some of these improvements have been implemented at disposal sites, but they have not been universally applied. In addition, some of these improvements may not be necessary or compatible with the conditions at a given site and should be considered only on a case-by-case basis. In this report, the suggested improvements applied in a manner which is compatible with site-specific conditions will be referred to as the upgrade of shallow land burial. Any upgrading will accommodate the same waste forms that are disposed by present practices. However, waste segregation and improved waste packaging will be desirable in certain situations.

The advantages of this alternative include:

o The technology exists.

- Sorption barriers and other engineered barriers could be readily accommodated.

o It could be implemented with only minor changes to existing waste management practices and without modifying present waste management transportation practices and regulations.

o Retrievability is possible. 
The disadvantages of this concept include:

- Higher initial costs than present shallow land burial would be incurred, although long term costs could be lower if the improved practices make future remedial measures unnecessary.

- Protection from natural and man-induced events is still relatively poor.

o Protection against deliberate and inadvertent contact is still relatively poor.

- At the end of its operational life, a disposal site could be released for only very limited use.

\subsubsection{Equipment and Facility Requirements}

The equipment and facilities required are the same as those currently used for construction and operation of shallow land burial sites.

\subsubsection{Unusual Operational or Maintenance Requirements}

The operational or maintenance requirements are expected to be similar to those currently used at existing shallow land burial sites, with the exception that certain improved operational practices are incorporated. Corrective maintenance required as a result of radionuclide migration should be less severe than that at many currently operating facilities.

\subsubsection{Geologic/Environmental Parameters}

Factors which affect isolation in shallow land burial and must be considered in site selection are: surface and groundwater occurrence and flow characteristics, topography and physiography, soil mass, physicochemical and engineered properties, active and potential geomorphic processes, present and future climatic conditions, and seismicity. These elements are best determined in context of their site, local and regional setting. 
The most important consideration for effective isolation of waste in shallow land burial is the potential for contact with surface and ground water. To preclude this potential a shallow land burial facility constructed above the water table and, more specifically, above the zone of ground water fluctuation is preferred. Therefore, the most desirable site setting is characterized by a relatively deep water table. The minimum distance between waste and underlying groundwater is site-dependent as determined from analysis of hydrogeologic conditions and containment medium properties. Conservative assurance against contamination of underlying water bearing horizons must be established, and sites where a hydraulic connection exists between waste and water resources must be avoided.

Soil is the containment medium for shallow land burial provided it is: 1) essentially homogeneous with respect to texture, 2) devoid of major irregularities, especially planar interfaces along which a marked contrast in soil properties occurs, and 3) impervious. Consolidated, fine-grained deposits are best for containment. In addition, the soil medium must be evaluated on the basis of specific physicochemical and engineering properties.

Fine-grained soil deposits are widespread throughout the U.S. and can be found within diverse terrains. Soils that are subject to dynamic processes such as surface erosion should be avoided. Soils in regions characterized by more catastrophic processes, such as tectonic instability and significant seismic ground motion, are unsuitable. However, many sites with suitable soils can be identified in the glaciated portions of the Northeast and Northcentral U.S., in thick residual soils of the Southeast, and in some intermontane valley-fill soils of the Basin and Range Province of the West, as well as elsewhere.

Consideration must be given to possible trench saturation and subsequent overflow, especially in regions of moderate mean annual rainfall. Infiltrating precipitation could ultimately result in land surface and ambient surface water contamination. During trench construction and waste emplacement, the influx of a large volume of precipitation must be avoided. Trench saturation during operation can be avoided by providing for impervious backfill and a vegetative cover, using approved soils in accordance with supervised compaction procedures, and by controlling surface drainage. 
Climatic conditions will affect groundwater conditions such that generally arid regions will have a deep water table whereas those with moderate to high mean annual rainfall normally will be shallower. Therefore, regions characterized by moderate to high mean annual rainfall are generally less desirable especially where underlying bedrock has low permeability. Some direct recharge will occur in either case, although the clay fraction of fine-grained soils (through cation exchange and adsorption) will help restrict transport of radionuclides by either subsurface vapors or liquids.

Finally, there must be conservative assurances that surface processes will not expose isolated waste or reduce the impervious nature of the isolation medium. The decay constants of critical radionuclides, such as $\mathrm{Sr}-90$ and $\mathrm{Cs}-137$ determine the required isolation period. It is assumed that waste decay time will not exceed the current interglacial stage and the long-range potential of glacial erosion. Moreover, regions of current or potential accelerated erosion should be avoided.

\subsubsection{Information/Technology Development Requirements}

No additional technology development would be required to implement this alternative. However, it would be desirable to obtain additional data on the effectiveness of the improvements and their usefulness in relationship to the time periods required for waste isolation.

More effective surface and subsurface monitoring and more detailed numerical modeling of groundwater and surface water flow at existing and potential sites would also be desirable.

\subsubsection{Related Investigations}

Two previous studies of alternative methods of disposal of radioactive waste have discussed improvements to shallow land burial. One of these reviews (105) considered the following modifications: 1) improved waste placement, 2) waste segregation, 3) engineered control of surface and ground water, 4) improved waste forms and packaging, and 5) improved administrative measures. This review concluded that, although these modifications had both advantages 
and disadvantages, they could increase the containment capability of burial sites. The cost to implement the modifications would probably increase present burial charges, but the cost savings associated with increased containment could overshadow these charges.

The modifications considered in the second review (67) include: 1) impermeable covers such as clay, concrete, asphalt, and stainless steel over trenches, 2) operational improvements, 3) improved waste forms, and 4) improved trench design. With the evaluation criteria and weighting scheme used, improvement of shallow land burial practices was judged to be the most desirable alternative to shallow land burial of the alternatives considered (i.e. improvements to shallow land burial, deeper burial, disposal in mined cavities, disposal in structural facilities, and ocean disposal).

A number of organizations and countries have either suggested shallow land burial improvements, proposed studies to improve shallow land burial, or reported investigations on selected shallow land burial improvements. These include :

o M. L. Wheeler, et.al. (117) discussed the benefits and disadvantages of several engineered containment, waste form, and administrative modifications to shallow land burial practices. They concluded that present practices could be modified to increase the containment capability of burial sites by emphasizing stable waste forms (additional use of solidification, compaction, and incineration and improved packaging), hydrologically oriented containment engineering (improved trench design, waste placement techniques, and trench encapsulation), and the natural materials surrounding the site.

- J. 0. Duguid (29) discussed the following items which have been instituted at various DOE sites to improve disposal operations:

1) improved record keeping and a centralized computer data file, 2) improved burial site surface maintenance and drainage control, 3) initiation of the use of waste compactors and current plans for their use at most burial sites, 4) initiation of studies at major sites for 
evaluation of the long-term impact of buried waste, 5) improvement of modeling/monitoring programs at all major sites, 6) initiation of studies to provide engineering methods of reducing burial ground discharges at ORNL, and 7) initiation of the shallow land burial technology program.

A report prepared for the U.S. EPA (88) summarized current engineering and water management practices that could be used at shallow land burial sites. These practices would minimize water infiltration from precipitation, thereby eliminating the potential to fill and overflow trenches and contaminate local ground and surface water. The recommendations given in the report are divided into these groups:

- Remedial steps for existing sites, such as providing access wells at the low end of a trench, modifying and improving trench covers, providing berms and drainage ditches, grouting, and injection of impermeable materials.

- New or improved practices for new sites, including better site selection, drainage of trenches prior to emplacing wastes, temporary berms, high compaction of wastes, moisture cells under trench cover in the trench bottom, immediate removal of any water detected, and properly designed covers.

- Post-closure practices, including control of vegetation; monitoring programs for ground and surface water, soil, and vegetation; and regular site inspections, especially following severe meteorological or geological events or changes such as torrential rains, tornados, hurricanes, heavy freezes, spring thaws, or earthquakes. program. Included in this program are improvements to shallow land burial practices which include erosion control, moisture control in buried waste, and site sealing. The overall program is expected to lead to site selection criteria, proper burial practices, waste preparation 
requirements, and a systems analysis method to determine the least costly approach for achieving LLW isolation in an environmentally acceptable manner.

T. Tamura (94) discussed results of studies on constructing chemical barriers to the migration of $\mathrm{Sr}-90$ in solid waste disposal area soils and on using a near-surface seal of bentonite and shale to impede infiltration.

o The evaluation of alternatives for long term management of stored Idaho National Engineering Laboratory (INEL) transuranic waste (100) considered three alternatives that are relevant to upgrading shallow land burial practices. The alternatives include various combinations of: 1) adding clay for sealing and basalt for erosion protection, 2) pressure grout sealing 1 to 2 meters below the stored waste which would minimize infiltration while retaining the ion retention properties of sediment below the waste, and 3 ) injecting grout into the waste and the sediment below it to immobilize the waste.

S. Ohmachi (74) discussed Japanese preparations for demonstration tests for land disposal of low level radioactive wastes scheduled for about 1980. Surveys, research, and tests related to waste packaging, waste segregation, evaluation of land disposal sites and designs, and testing methodology are being conducted in support of the program.

o D. H. Charlesworth (17) summarized Canada's development programs for the disposal of low and intermediate level wastes. He indicated that, although the disposal of all wastes at a single, shared, hard rock site is Canada's preferred option, they are planning preliminary assessments of shallow land burial in an unsaturated zone.

- Y. Sousselier and A. Redon $(78,86)$ both reported that studies are underway in France to improve shallow land burial with capillary barriers using layers of fine and coarse sand and gravel. 

and Development (73) reported that an International Atomic Energy Agency Advisory Group which reviewed shallow land disposal concluded that it would be a safe and inexpensive option for short-lived wastes if:

- Containment was ensured by the geological medium

- Threshold limits for concentrations and total amounts of long-lived nuclides were established on a case-by-case basis considering a predetermined containment time and local environmental conditions.

- The Commission of the European Communities (21) has suggested, in their recent "Proposal for a Second Five Year Programme (1980-84) on Radioactive Waste Management and Storage," that problems relating to shallow land burial of solidified waste be studied. Their proposed program includes: 1) evaluation and comparison of current in situ experience, 2) investigation of radionuclide migration and safety aspects considering the influence of artificial barriers, and 3 ) improvement of shallow land burial techniques.

\subsection{INTERMEDIATE DEPTH BURIAL}

\subsubsection{Description and Application}

Trenches of sufficient depth to allow a soil covering of 10 to 20 meters would be used in disposing of LLW by intermediate depth burial (67). Depending on the location of the water table with respect to the buried waste, this alternative includes two distinct concepts for achieving waste isolation. If the waste is located above the water table as would be the case for most western U.S. diposal sites, the concept is very similar to shallow land burial discussed in the preceding sections with the exception that the additional soil covering in intermediate depth burial provides more protection against unauthorized contact and natural events than is provided by shallow land burial. If the waste is located below the water table as it would be at most eastern U.S. locations, waste isolation can be achieved by emplacing the 
waste in media in which groundwater flow is controlled by molecular diffusion. The description of intermediate depth burial includes separate discussions of these two distinct concepts where appropriate.

All forms of LLW that are presently being disposed of using shallow land burial could be disposed of using intermediate depth burial. However, more extensive use of compaction and/or incineration may be necessary to prevent undermining of backfill material.

The advantages of intermediate depth burial include:

o In comparison with shallow land burial, this alternative would reduce the possibility of inadvertent contact with the buried waste and make it less vulnerable to natural events.

o The technology exists for implementation.

o There is good protection against deliberate and inadvertent contact.

o Sorption barriers and other engineered barriers can be readily utilized.

- Retrievability is possible.

- The disposal site can be released at the end of its operational life for most surface and near surface uses.

- Implementation is possible with present LLW shallow land burial practices, transport, and regulations.

o Land could be restored at abandoned strip mines if the geologic and hydrologic conditions at these locations are suitable. 
The disadvantages of disposing of LLW by intermediate depth burial include:

o The initial costs would be higher than for current shallow land burial. Long term costs could be lower if the alternative provides definite containment during the period the waste is hazardous, thus making future remedial measures unnecessary.

\subsubsection{Equipment and Facility Requirements}

o Excavation

Equipment such as draglines would be needed to dig the deeper trenches as opposed to backhoes or grade-alls for shallow depths.

- Waste Receiving Area

The waste would be removed from the transport vehicle, inspected, and placed in a staging area if trench preparation was not complete. If a trench was ready to accept waste, the container would be directly emplaced in it.

- Waste Documentation

Within the staging area, waste canisters would be readied for disposal. The waste type, activity, geometry, and physical and chemical characteristics would be logged and tagged.

- Waste Transfer

Appropriate transfer equipment, such as truck or track vehicles with transfer casks, etc., would be used for moving waste to the trench area. Waste could be placed by mobile jib crane or gantry type cranes (Figure 3-1) and this placement could be monitored. Material handling equipment compatible with packaging would be required. 


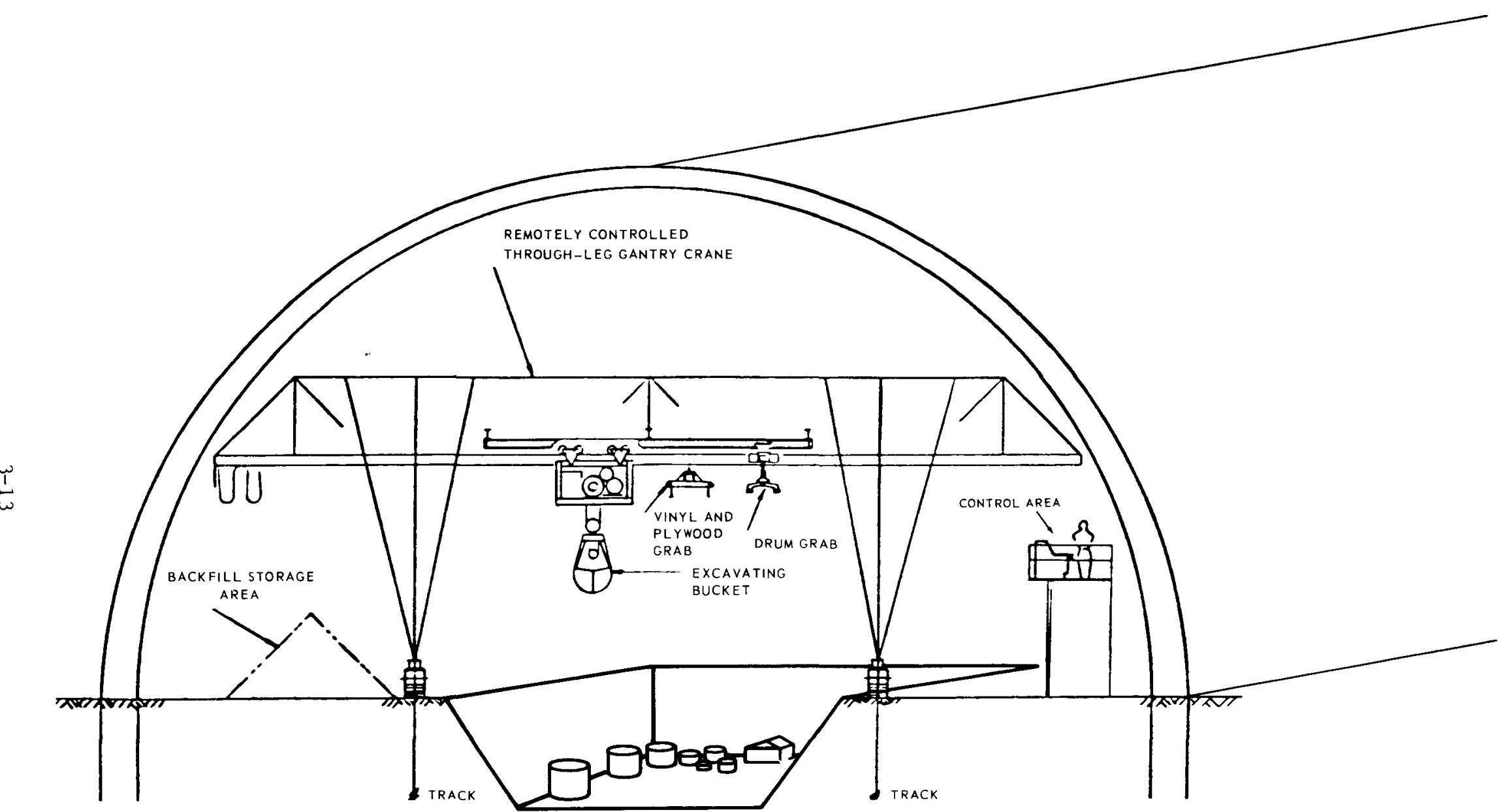

FIGURE 3-1

MOBILE GANTRY CRANE FOR INTERMEDIATE DEPTH WASTE PLACEMENT 


\subsubsection{Unusual Operational or Maintenance Requirements}

The operational and maintenance requirements are almost the same as for shallow land burial.

\subsubsection{Geologic/Environmental Parameters}

The geologic and environmental parameters in intermediate depth burial, generally are comparable to shallow land burial as discussed in section 3.1.4. However, intermediate depth burial waste isolation occurs beneath a considerably thicker backfill cover. Consequentially, an increased in situ soil thickness is most desirable. Unlike shallow land burial, waste isolation for intermediate depth burial could be designed to occur below or above the water table.

Intermediate depth burial would involve waste isolation beneath a thick soil cover. Ideally, the soil would possess a high sorptive capacity for radionuclides in the waste. The volume of soil cover material required may be obtained locally during excavation for the intermediate depth burial facility. Sites, even with substantial soil thicknesses, may be unsuitable if migration along a soil-bedrock interface is possible prior to decay of radionuclides in the waste (19).

Under optimum conditions, intermediate depth burial would occur above the groundwater table and, specifically, above the zone of groundwater fluctuation, as discussed in Section 3.1.4. $(19,67)$ However, the likelihood of encountering a greatly depressed water table an acceptable distance below the waste decreases as the placement depth increases. An acceptable distance from water table to waste would be a minimum of several meters depending on the range of water table fluctuation. (67)

Waste could also be placed within the saturated zone provided placement is below the zone of water table fluctuation (18). The containment medium would be a homogeneous soil characterized by exceedingly low primary and secondary permeability. Under these conditions, contamination beyond the waste is 
restricted to molecular diffusion. However, the probability of encountering fractures in the soil medium increases as the disposal trench area increases. Construction of artifical barriers completely enclosing the waste may be necessary, if not prudent, in order to avoid radionuclide migration within groundwater.

The hydrogeologic potential for waste leakage from a consolidated, impervious soil deposit must be established. If waste is located above a depressed water table, the primary transport mechanism for leakage is avoided, provided no hydraulic connections, such as fractures, extend into the saturated zone. (18, 19, 67) Isolation below the water table will result in flow into the "dry" disposal zone (18) until saturation occurs. Thereafter, the movement of waste contaminants is controlled by the prevailing site groundwater conditions. Whether disposal occurs above or within the saturated zone, sites where a hydraulic connection exists between waste and a water resource must be avoided.

The geographic locations of interest, for intermediate depth burial above the water table, are as discussed in Section 3.1.4. However, for burial below the water table, the widespread till and glaciolacustrine deposits in Northeastern and North Central U.S. are considered the most promising unlithified soil containment media candidates. Extremely dense till and glaciolacustrine deposits contiguous to the Great Lakes and within the St. Lawrence River Valley regions have been encountered during construction. Many of these deposits are thicker than 30 meters and might be developed as disposal sites. Less widespread and more randomly located glacial deposits in the Northern Rocky Mountain region and Northwestern U.S. may also be suitable.

A potential exists within dense till for joint system development inherited from underlying bedrock. Site and regional exploration and testing are necessary in evaluating joint development. Although till moisture content is characteristically low, especially for very dense impervious deposits, a normal hydrostatic gradient is typical and an exceedingly low groundwater velocity can be anticipated, usually less than $10^{-8} \mathrm{~cm} / \mathrm{sec}$. Homogeneity of till deposits can be expected with occasional lenses of more permeable, 
coarse-grained sediments. Till sheets deposited during different glacial stages may be bounded by nearly horizontal contacts along which fluid or groundwater migration may occur. Other glacial deposits, notably glaciolacustrine sediments, are stratified and usually characterized by extremely low vertical permeability. In many cases, horizontal permeability also may be sufficiently low and within limits for isolation media.

Abandoned strip mines, which could be used for intermediate depth burial, would be available in many Eastern U.S. coal fields. Current Federal mining reclamation regulations require the restoration of strip mines to pre-mining topography before abandonment. Many additional sites, especially in the Western U.S. coal fields with continuous cut and fill operations, might be adapted to waste storage. Abandoned metallic deposit strip or open-pit mines probably are unsuitable as the potential for future extraction of unmined low-grade reserves is always a possibility.

\subsubsection{Information/Technology Development Requirements}

Although the use of intermediate depth burial for the disposal of LLW has not been demonstrated, no technology development should be required. However, the relatively remote depth of isolation makes it difficult to monitor any potential leakage. Standard devices such as piezometers are inappropriate because they compromise the integrity of isolation. Moisture resistivity devices buried in proximity to waste and attached to monitoring stations could detect groundwater attack. This method would serve only as an indirect indicator of potential leakage. Additional research in monitoring and modeling methodology may be required depending on individual site hydrogeologic conditions.

\subsubsection{Related Investigations}

Intermediate depth burial above the water table was evaluated in a previous study $(66,67)$ of alternative methods of LLW disposal performed by Macbeth et al. They concluded that intermediate depth burial of LLW was a feasible alternative. With the evaluation criteria and weighting scheme used in their 
evaluation, it compared favorably with some of the other alternatives considered (engineered facilities, new mines, acceptable abandoned mines, and ocean disposal) but less favorably with improvement of present shallow land burial practices.

A study performed by Cherry et al (18) is relevant to intermediate depth burial below the water table. Cherry's study considered the use of drilled holes instead of excavated trenches but the waste isolation concept is identical to that of intermediate depth burial below the water table. In Cherry's concept, isolation is achieved by locating the waste in the core of a till sheet or glaciolacustrine deposit in which hydraulic flow is insignificant and groundwater movement is controlled by molecular diffusion. In such a formation, leachate from the waste will not be hazardous when it reaches the biosphere because thousands of years would be required for it to travel through the many meters of clay or clayey till surrounding the waste. The major uncertainty with regard to Cherry's isolation concept is the effect of fractures extending far below the water table that are known to occur in some parts of the glaciated regions of North America. Site specific investigations are required to determine whether such fractures would result in groundwater movement not being controlled by molecular diffusion.

\subsection{DISPOSAL IN ENGINEERED FACILITIES}

\subsubsection{Description and Application}

LLW disposal in engineered facilities would use man-made structures to store waste during its hazardous lifetime. The facilities could be above or below ground and designed for the expected conditions at a wide range of sites. Of the various types of facilities that could be used, a cast-in-place reinforced concrete structure would have the best resistance to corrosion and weather, be the most impermeable, and remain intact the longest $(66,67)$. This concept relies on the ability of the building and any engineered barriers to isolate the waste from the biosphere. All forms of LLW could be disposed of in engineered facilities. However, volume reduction of the waste to minimize the size of the facilities required would probably be economically desirable. 
The advantages of this concept include:

o The ability to locate the facility independent of most geologic constraints would make it possible to minimize the risk associated with waste transportation and handling.

o The technology exists to implement this technique.

o Retrievability is possible.

o Sorption and other barriers could readily be accommodated.

o Monitoring for leakage could be performed easily.

- Existing waste practices can be used.

The disadvantages of this concept include:

o Higher initial costs than shallow land burial would be incurred. Comparison of long term costs with those expected to be incurred in present shallow land burial practices cannot be made without detailed investigations beyond the scope of this review.

- The protection from natural events is dependent upon the initial design criteria and the continued integrity of the building, which would be expected to degrade with time.

o Continued maintenance and surveillance would be necessary for many generations.

- Because of the proximity of the facility to man's activities, protection from deliberate contact and man-induced events is questionable.

o The continued isolation of the waste over its hazardous lifetime is questionable. 
Neither the facility or the site could be released for use at the time the facility reaches its capacity.

\subsubsection{Equipment and Facility Requirements}

The facility must be designed to meet the geological and environmental conditions (i.e. seismic accelerations, flood levels, etc.) For example, an underground facility should not be placed in a flood plain or in any area known to be seismically active.

The facility could be designed using a warehouse or compartmentalized storage arrangement. Figures $3-2$ and $3-3$ show storage arrangements using both concepts.

The facility must contain a receiving area in which all transported wastes to the facility can be removed from the transport mechanism (truck, rail car, etc.). The facility must be capable of monitoring radiation levels associated with the waste shipment and have the capability to perform any maintenance to equipment to ensure the safe handling of the waste containers from the receiving point through the final storage location.

Documentation of waste source, activity, volume, monitoring, etc., must be recorded and retained during facility operation.

The facility should be operated to allow selective segregation of storage containers. This allows different levels of wastes to be segregated as required. 

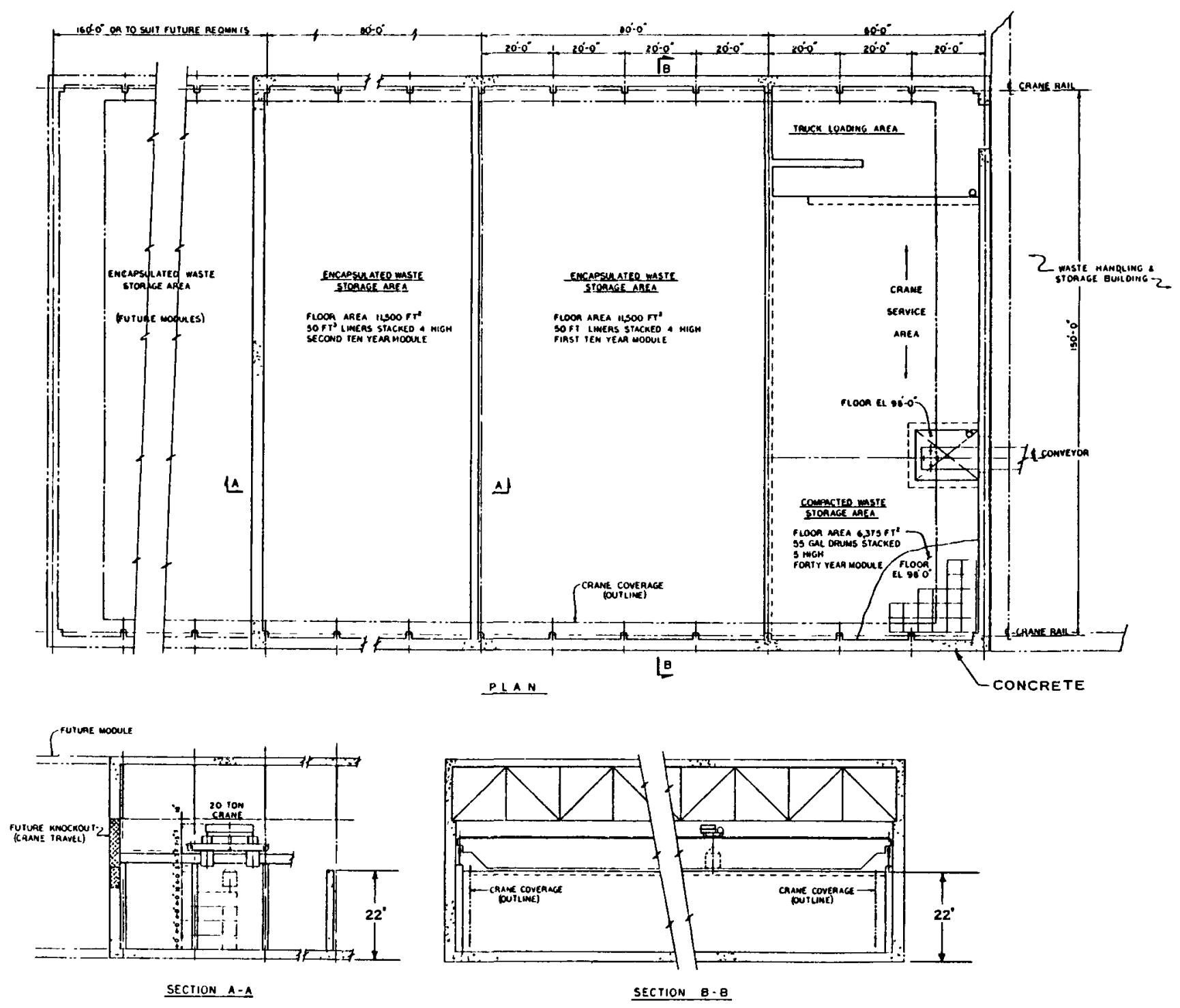

FIGURE 3-2

WAREHOUSE TYPE ENGINEERED FACILITY 


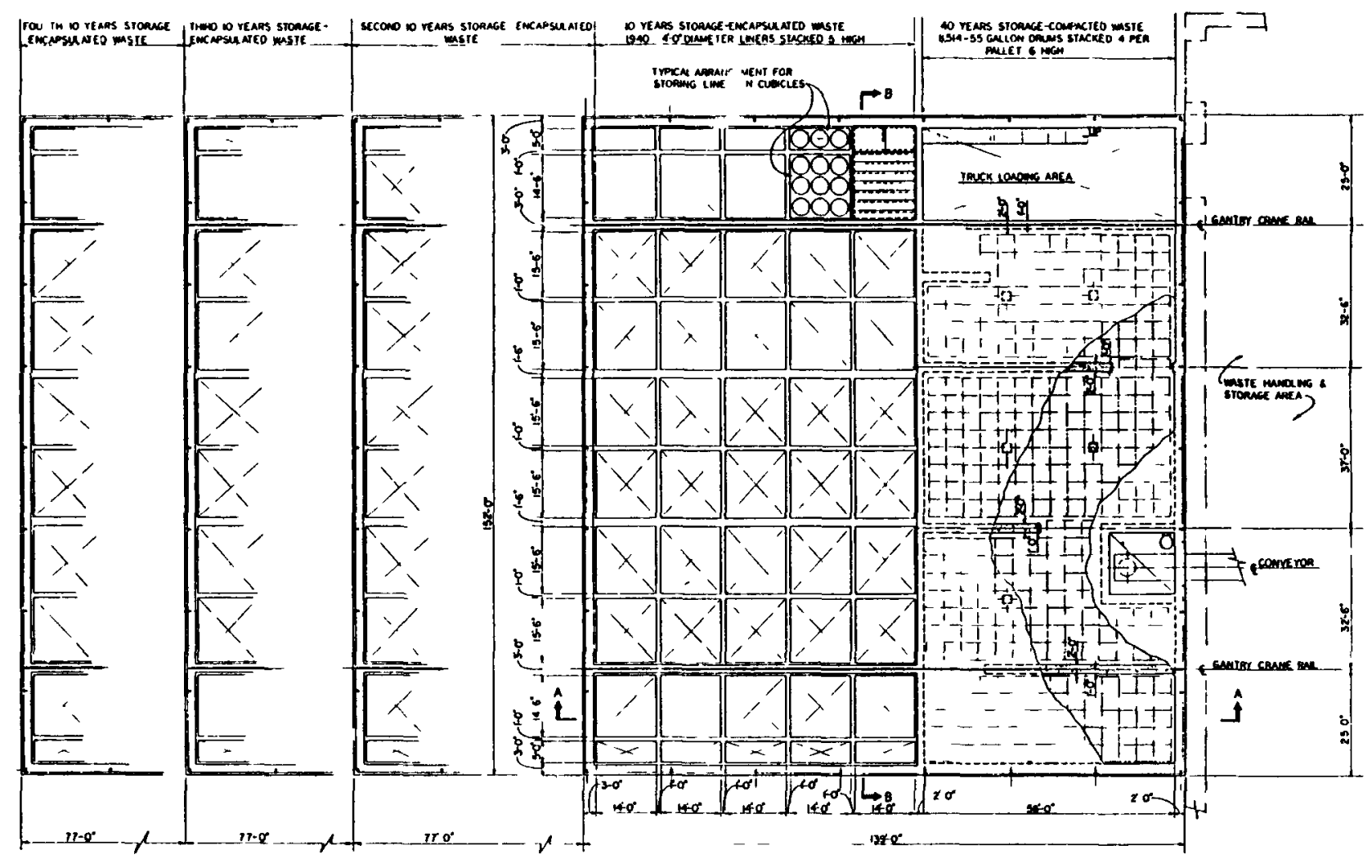

PLAN 
If the underground facility has a receiving building located at ground level, a mechanism would be required to move the waste container from this building to the storage building receiving area. A monorail with hoist or another type of overhead crane could be used.

The storage building should have some mechanism for moving storage containers to their final location. A gantry crane or some type of underhung bridge crane could be used. These types of cranes provide the greatest range of coverage for this type of facility.

\subsubsection{Unusual Operational or Maintenance Requirements}

The assurance of continued facility integrity is of major concern. For an above ground facility, visual inspection of the building perimeter and nondestructive testing methods could provide this assurance. For an underground facility, an access or inspection tunnel around its exterior perimeter could be used in a similar manner.

\subsubsection{Geologic/Environmental Parameters}

Although the concept does not rely on geologic isolation, site geotechnical conditions governing foundation design would be considered during the facility design. Shallow isolation of released radionuclides would be controlled by geologic parameters similar to those discussed in Section 3.1.4 for shallow land burial. For leaks to the atmosphere, there is no protection other than that provided by the building and its engineered barriers. Zones of crustal instability and active faults should be avoided during site selection. The design ground motion acceleration should be based on local and regional seismic history. 


\subsubsection{Information/Technology Development Requirements}

There is no technology or information development (other than data required for design of the facility) required for implementation of this concept. However, it would be desirable to investigate: 1) multiple engineered barriers to prevent releases, 2) possibilities of reducing the threat of unauthorized intrusion, and 3 ) methods of assuring the integrity of the engineered facility while the waste is hazardous.

\subsubsection{Related Investigations}

Macbeth and his co-workers reviewed this alternative in a previous study (66, 67 ) of alternative methods of LLW disposal. They concluded that an engineered facility was a feasible disposal alternative. With the evaluation criteria and weighting scheme used in their review, engineered facilities compared the least favorably of the alternatives considered.

A number of countries are using engineered facilities for long-term storage of LLW. Most are doing this as an interim measure while investigating disposal alternatives $(15,78,86)$. However, three countries have given the following indications that engineered facilities may be the disposal method for at least some of their LLW:

o France is considering long-term storage in engineered facilities for disposal of fission products (41).

- Ontario Hydro, a Canadian utility, uses several types of engineered facilities for storage of LLW including: 1) in-ground reinforced concrete trenches for storage of processed and nonprocessible lower level reactor wastes; 2) below ground vertical tile hole facilities for storage of higher level cartridge and packaged ion exchange resins; and 3) above ground, double containment quadricell modules for storage of bulk quantities of ion exchange resins and reactor core components. They feel that some of these wastes may not be transferred to other storage facilities or future disposal sites. Consequently, they have considered 
details in facility design which would contribute to the long-term durability of their facilities (15, 110, and personal communication with T. J. Carter, 1979).

- Czechoslovakia is planning to use an engineered facility consisting of reinforced concrete pits covered with panels and 0.6 meters of soil for disposal of low and intermediate level wastes. The facility is scheduled to be operational in 1983. The site selection procedure for the facility will include criteria to help locate sites with favorable geological and hydrological characteristics (28).

The evaluation of alternatives for long-term management of stored INEL transuranic waste considered six concepts that are relevant to using engineered facilities for waste disposal (100). The concepts involve building a structure of large interlocking concrete blocks above or below ground but above the water table with layers of clay, bentonite, and basalt covering the facility. The interlocking blocks provide a high degree of flexibility by redistributing stresses due to relative motion rather than cracking or shearing as would be expected in a rigid structure. Most of the concepts considered were characterized by a high ratio of reinforced concrete to void. Because of the unfavorable cost of these massive designs, a less massive variation was developed and included in their evaluation.

\subsection{DISPOSAL IN DRILLED HOLES}

\subsubsection{Description and Application}

This type of LLW disposal involves drilling large-diameter holes in appropriate geological media, emplacing the wastes, and sealing the holes. The holes can be from tens to hundreds of meters deep. In this range of depths, the waste can be above or below the water table depending on site-specific conditions. Isolation of wastes located above the water table is dependent upon minimizing contact between water and the buried waste. Isolation of wastes located below the water table is dependent upon locating the waste in a formation in which groundwater flow is slow in comparison to 
the time required for waste isolation. This alternative is thus very similar to intermediate depth burial. The main difference is that drilled holes can be used to much greater depths than can intermediate depth burial.

Al1 forms of LLW except large pieces of contaminated equipment can be disposed within drilled holes. Certain waste types may require compaction or incineration to assure that undermining does not compromise borehole seal integrity. More extensive use of methods to reduce waste volumes may be economically desirable.

The advantages of this concept include:

- A high degree of isolation and protection from natural and man-induced events are possible.

o Drilling technology exists to implement this technique.

o There is good protection against sabotage and inadvertent contact.

- Some degree of retrievability is possible (by reaming to the top of the wastes and using a specially designed core barrel to lift the waste containers and surrounding material).

o Sorption barriers and other engineered barriers could readily be accommodated.

- The disposal site can be released at the end of its operational life for uses not involving drilling or excavating to the range of depths used for waste emplacement.

- The HLW disposal program results can be used, since deep holes are to be studied as an HLW disposal alternative (52).

- Disposal of HLW and LLW in the same formation is possible if this alternative is implemented for HLW disposal. 
The disadvantages of disposing of LLW in drilled holes include:

o Higher costs than shallow land burial would be required.

- The numerous drill holes that would be required for LLW disposal would increase the probability that, even with proper borehole sealing, the containment capability of the disposal formation would be compromised.

- The concept has not been studied as extensively as some of the other alternatives discussed in this report.

\subsubsection{Equipment and Facility Requirements}

A surface facility similar to that discussed in Section 3.2 .2 would be required. The facility would include provisions for unloading the waste containers and providing temporary storage. The facility would also include provisions for monitoring the waste containers and documenting the physical and chemical characteristics of the waste. Tracked vehicles or remotely operated cranes could be used for transferring waste containers from the staging area to the disposal hole.

Large diameter caisson drilling equipment would be necessary for drilling the waste emplacement holes. For relatively shallow holes in homogenous fine-grained soil free of large rock fragments or boulders, hole diameters up to 4.9 meters ( $16 \mathrm{ft}$ ) can be attained with existing caisson excavation equipment. Considerably deeper holes with a diameter of 4.3 meters (14 ft) have been excavated into bedrock with "Hughes Down Hole Drills" (personal communication with Mr. William Murphy, Case International, 1979). Conventional "shot and blast" methods can also advance large diameter shafts through rock to considerable depth.

\subsubsection{Unusual Operational or Maintenance Requirements}

Protection of the drilled holes from precipitation, surface runoff, and groundwater would be required from the time the holes were drilled until the sealing of the hole after waste emplacement. Protection from precipitation 
could be provided by a temporary enclosure covering the area in which the holes were located. Diversion ditches could protect the holes from surface runoff. Casing the holes after drilling would protect them from groundwater infiltration.

\subsubsection{Geologic/Environmenta1 Parameters}

The geologic and environmental parameters for the drilled holes method of disposal, especially for storage above and within groundwater are comparable to those discussed in Section 3.2.4. However, in drilled holes, bedrock masses can also be considered in the selection of candidate isolation media.

Several materials are acceptable as isolation media provided they are: 1) physically homogeneous; 2) devoid of large numbers of discontinuites such as fractures (i.e. joints, faults); 3) structurally uncomplicated; and 4) impervious. Waste storage above and within groundwater is discussed in Sections 3.1.4 and 3.3.4. In either case, storage within the zone of water table fluctuation should be avoided. Dense, fine-grained, glacial and glaciolacustrine deposits may be considered as in Section 3.2.4. Shale, granite, basalt, and salt are general bedrock types which may also be considered. Carbonate bedrock is considered unsuitable as this rock type may have undergone considerable dissolution during its geologic history resulting in the development of complex solution channels and enlargement of fracture openings. Both conditions compromise the integrity of isolation and are difficult to detect. Each candidate medium, either rock or soil, must be evaluated on the basis of its respective specific physicochemical and engineering properties as well as site conditions.

The geographic locations for dense, fine-grained deposits are discussed in Section 3.2.4. Bedrock suitable as containment media are distributed throughout the continental U.S.

Fracturing should be anticipated for bedrock storage media. The extent and degree of fracturing can be assessed from site exploration and testing. If the extent and frequency of fracturing is minimal, the introduction of an 
engineered sealant, such as grout curtains, should retard the migration of radionuclides by other than molecular diffusion. Salt, an exception to other bedrock storage media, may be free of fractures because of its property to deform plastically in relatively brief geologic time, thereby effectively sealing fractures. However, since salt can rapidly dissolve in salt-free groundwater, storage should be above the water table or in salt saturated groundwater.

Isolation within a suitable rock mass could occur down to 1,000 meters. Therefore, regions characterized by an unusually high geothermal gradient, structural complexity, and high state of in situ stress should be avoided. Rocks with existing or potential future economic worth should not be considered because nearby mineral and hydrocarbon extraction could alter groundwater conditions and induce fracturing.

\subsubsection{Information/Technology Development Requirements}

This alternative would use conventional surface facilities and equipment and conventional drilling and borehole sealing techniques. Consequently, no new technology development is anticipated. However, development of the following items should be considered if this alternative is implemented:

- Methods of adequately sealing the boreholes that are both low in cost and adequate for waste isolation.

o An effective, continuous, in situ monitoring system to compare any vertical or lateral movement of radioactive isotopes. Diffusion of the radionuclide front will occur independent of isolation effectiveness; this should be compared with predicted migration and/or diffusion rates from the isolated waste source.

Data will be required on the expected integrity of the borehole seals for the time required for LLW isolation. 


\subsubsection{Related Investigations}

Two previous studies of alternative methods of disposal of radioactive waste have discussed this alternative. One of these reviews which emphasized HLW disposal (105) concluded that the potential of the concept justified at least a feasibility study. The other review, which screened and evaluated LLW diposal alternatives $(66,67)$, concluded that this alternative was technically feasible, but it was not included in the evaluation portion of the review.

The concept of using drilled holes above the water table for HLW storage has been investigated by I. J. Winograd of the United States Geological Survey (118). J. A. Cherry of the University of Waterloo (18) has investigated drilled holes below the water table for LLW disposal. The use of very deep, drilled holes is one of the alternatives considered in the "Draft Environmental Statement for the Management of Commercially Generated Waste" (101). The results of these studies are discussed below.

Winograd's investigation considered the use of drilled holes in very thick, unsaturated zones in arid regions such as those found in the Southwestern United States for storage of HLW. The use of drilled holes was not crucial to his investigation but was considered because it appeared to minimize both cost and disruption of the landscape. He concluded: 1) storage above the water table in thick, unsaturated zones appears suitable for isolating such long-lived fission products as $\mathrm{Sr}-90$ and $\mathrm{Cs}-137$ from the hydrosphere and biosphere for the approximately 600 to 1,000 years needed for decay of these nuclides, 2) the concept offers the potential for retrievability and only nominal surveillance, and 3 ) additional research would be required to define ambient movement and content of water and gases in common rocks comprising the thick unsaturated zones of interest.

Cherry's investigation which has been previously discussed in Section 3.2.6 considered the use of drilled holes in fine-grained deposits for disposal of LLW. The wastes would be emplaced many meters below the level of water table fluctuation. In this environment, molecular diffusion, which is a very slow process, will be the main mechanism by which radionuclides will migrate from the drilled holes. Cherry and his co-workers concluded that: 1) radionuclides 
such as $\mathrm{Sr}-90, \mathrm{Cs}-137, \mathrm{Co}-60$, and $\mathrm{H}-3$ will decay to insignificant levels before reaching zones of active groundwater flow, if these zones are separated from the waste by many meters of dense, relatively unfractured, clayey till or clay; 2) radionuclides such as $\mathrm{C}-14$ or Ra-226 will diffuse into the biosphere after a period of thousands of years or longer, but the radionuclide flux to the environment would be small; 3) the wetting-up period after waste emplacement. may be delayed considerably by using materials such as swelling clays or oxides of magnesium and aluminum; and 4) concentrations of $\mathrm{H}-3,0-18$, $D, C-13$, and $\mathrm{C}-14$ in the pore water of deposits being considered for waste emplacement can be used to determine if groundwater flow in the deposits is in fact insignificant. Cherry's investigation is expected to be followed by a preliminary assessment of the concept as part of the Canadian waste disposal program (17).

The use of very deep drilled holes is one of the alternatives considered in the Draft Environmental Statement for the Management of Commercially Generated Radioactive Waste (101). The concept has been recommended for funding by the Interagency Review Group (52) so that it can be evaluated as a potential competitor to HLW disposal in mined repositories. The depth of hole being considered for HLW disposal would probably not be required for LLW. However, if the use of drilled holes for disposal of LLW is an alternative that is chosen for additional investigation as part of the LLW program, there are several ways in which results from the HLW program could prove beneficial (assuming the Interagency Review Group (IRG) recommendations are implemented). These include:

Site selection - Any search for demonstration sites, experimentation, or disposal of HLW will be useful to the LLW program, since the sites identified and screened during this search can also be reviewed as potential LLW disposal sites.

- Use of sites inadequate for HLW disposal - Sites evaluated and rejected for HLW diposal (for example, because of thermal criteria) may be adequate for LLW disposal. 
o Collection of site-specific data - Much of the data collected at a site to evaluate its ability to isolate HLW will be applicable to LLW diposal.

o Evaluation of containment integrity - Many of the evaluations performed for HLW will not have to be repeated for LLW.

o Co-location of HLW and LLW - If very deep holes are used for disposal of HLW, LLW could possibly be emplaced in the same holes at elevations above the HLW.

o Borehole sealing - Data and technology on borehole sealing developed for the HLW program may be applicable to LLW disposal in drilled holes.

\section{$3.5 \quad$ DEEP WELL INJECTION}

\subsubsection{Description and Application}

Deep well injection involves pumping liquid waste into sufficiently porous or fractured strata to displace existing fluid (Figure 3-4). The waste remains in the liquid form, diffusing and dispersing throughout the strata. The waste liquid is accommodated in the formation by displacing any existing fluid and possibly expanding the formation. To achieve isolation, the injection formation must be confined by relatively impermeable media and be sufficientlyr deep to be isolated from aquifers that could be water sources for drinking, irrigation, industrial production, etc. Reportedly, the acceptable depths for deep well injection waste isolation are from about 1,000 meters to the 5,000 meters limit of present technology (101). The media comprising the host strata may also retain some of the injected radionuclides but this is not the primary isolation mechanism.

Only liquid LLW that is physically and chemically compatible with the injection formation could be disposed of using this alternative. This would require liquid waste with very low suspended solids that was appropriately buffered to prevent dissolved solids from precipitating. The disposal formation may also have to be flushed with chemical solutions to adjust the formation chemistry prior to waste injection. 


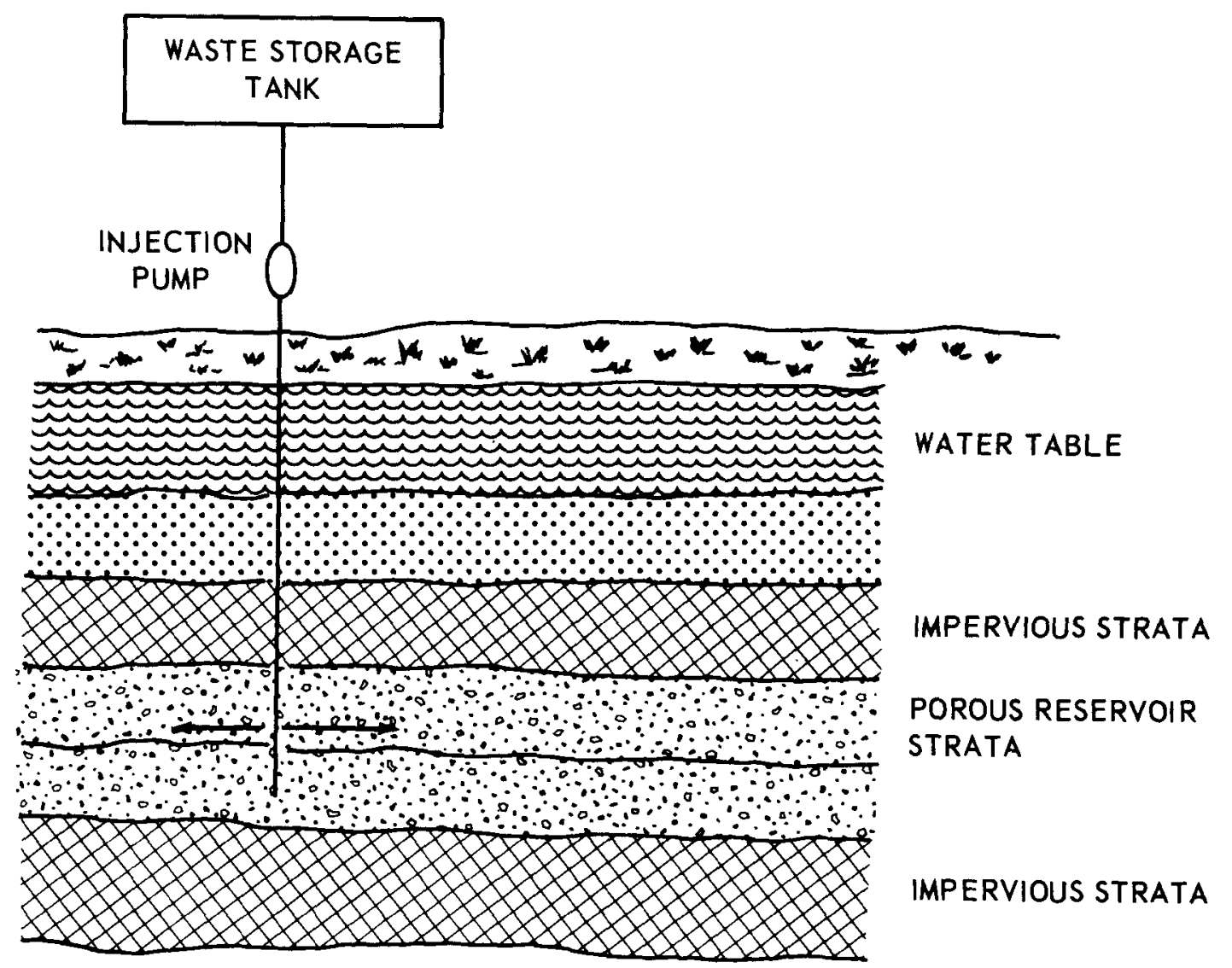

FIGURE 3-4

SCHEMATIC OF DEEP WELL INJECTION

(ADAPTED FROM REF. 98) 
The advantages of this concept include:

o The drilling and injection technology exists to implement this alternative for liquid waste.

- Some degree of retrievability is possible (since the waste will remain in a liquid form, it will be possible to drill to the disposal formation and pump the fraction of waste that had not been retained by sorption on the disposal media. An additional fraction of the waste could be retrieved if desired by injecting an acidic solution into the formation and pumping the resulting fluid to the surface) (101).

o There is good protection against catastrophic natural events.

o The disposal site can be released at the end of its operational life for most uses not involving excavating or drilling to the range of depths used for waste emplacement.

The disadvantages of this concept include:

o Higher initial costs than shallow land burial would be required. Comparison of long term costs with those expected to be incurred in present shallow land burial practices depends on the degree to which remedial measures are necessary for each disposal method.

- Sorption and other barriers could not be accommodated although it may be possible to use disposal formations with high sorptive properties.

o The form of waste that can be disposed of is restricted to liquids that are physically and chemically compatible with the disposal formation.

o Stimulation of seismic activity as a result of the injection is possible.

o The waste is left in a relatively mobile state, and lateral or vertical migration to groundwater aquifers is a possibility. 
Inadvertent and other unauthorized contact is possible using standard well equipment.

The U.S. Environmental Protection Agency opposes deep well injection unless: 1) all reasonable alternative measures have been explored and found less satisfactory in terms of environmental protection; 2) it can be clearly demonstrated that deep well injection will not interfere with present or potential use of the subsurface environment; 3 ) the injection process is strictly controlled and monitored; and 4) adequate measures are available to provide protection against well failures (34).

\subsubsection{Equipment and Facility Requirements}

The equipment and facilities required for this alternative depend on the assumptions made about the form in which the waste is received and the location of the disposal facility with respect to the source of the waste. The requirements given in this section assume that the disposal facility is located adjacent to the waste generating facility and that the disposal facility receives the waste in a liquid form (equipment in addition to that given below would be required to store, liquify, treat, etc., if the waste were received in a solid form).

A waste treatment facility would be needed to filter and chemically adjust the liquid waste to make it compatible with the disposal formation. Storage tanks and transfer pumps would hold and transfer the waste as required. Injection and retrieval pumps, plus tanks of buffering solution required in the pretreatment of the disposal formation, would be located at the injection well. Equipment would also be required to treat spent buffering solutions for discharge or reuse.

\subsubsection{Unusual Operational or Maintenance Requirements}

Prior to using any disposal formation, any drill holes violating the integrity of the strata overlying the disposal formation would have to be located. These drill holes, along with any exploratory holes used in evaluating the 
formation, would have to be sealed prior to waste injection. The continued integrity of the seals should be checked during and after waste injections.

As mentioned previously, the injected waste must be chemically and physically compatible with the disposal formation. This could require flushing the formation with water or chemical solutions that would adjust the formation's chemistry .

Provisions must be made for monitoring the injection process, movement of waste in the disposal formation, potential contamination of groundwater outside the disposal formation, induced seismic activity, and integrity of the impermeable strata overlying the disposal formation. This would assure proper functioning of the injection process and the continued integrity of the disposal formation. The monitoring could be performed using conventional process and seismic monitors and appropriately instrumented and cased observation wells.

\subsubsection{Geologic/Environmental Parameters}

Deep water-bearing horizons are the repository media for this concept provided they are: 1) confined by impervious strata,2) located within a zone of stagnant or exceedingly slow water movement, 3) sufficiently porous or fissile to accommodate injected waste, 4) structurally uncomplicated, and 5) devoid of discontinuities. (87)

Sandstone $(98,99,101)$ and, possibly, vesiculated basalt flows are considered the primary injection repository media. Carbonate bedrock such as limestone and dolomite may be considered, provided they are sufficiently fractured, and only neutralized supernates are injected (see especially Ref. 101). Fluids or gases occupying intraformational, intergranular space will be displaced by injected waste. Under preinjection saturation conditions, increased formation pressures attributable to injection may compromise containment by rupturing the confining strata. Holes drilled into the host rock could enable fluids to be withdrawn synchronous with injection, thereby providing sufficient room for waste. However, unavoidable contamination of the withdrawal fluid is likely 
to occur. Gases could dissolve within the injected mass, although adverse reactions could result during mixing of this type. Summarily, the physicochemical and engineering properties of the host rock as well as the fluids and gases it contains must be well understood, along with the effects of injection waste on each.

Maintenance of a buffer between the waste formation fluids and gases could minimize intraformational contamination. Even though intergranular movement within the host rock medium ideally will be restricted, molecular diffusion of radionuclides through this buffer will take place. Therefore, consideration must be given to buffer solution diffusion properties and reaction potential.

Sedimentary basins containing suitable host rock strata, sufficiently deep, porous (or fissile) and confined, are abundant throughout the U.S. Basalt flows meeting the generic criteria are probably restricted to the Columbia River Plateau Province of the Northwest U.S.

A minimum acceptable depth for the disposal horizon is about 1,000 meters (101). The considerable depths at which waste storage could occur suggest than an abnormally high geothermal gradient, as well as other in situ conditions, could adversely affect waste materials. Moreover, deep well injection has the potential for stimulating seismic activity which could compromise confinement and create pathways to the biosphere $(68,101)$. The release of seismic energy by deep well injection would most likely occur in regions characterized by tectonic instability. Unsuitable sites can be avoided through site selection screening including in situ testing.

\subsubsection{Information/Technology Development Requirements}

Deep well injection of liquid waste has been used by industry to dispose of a variety of nonradioactive wastes. Consequently, the technology for implementing this alternative for liquid radioactive waste is well developed. For this alternative to have general applicability to LLW, it would be necessary to develop processes (or adapt existing processes such as acid digestion) that would make it possible to easily convert the various LLW forms into a liquid that could be injected into the disposal formation. This would 
probably require changes in the form in which wastes are shipped to disposal sites and could thus require changes in existing waste transportation regulations. Alternatively, this technique could be limited to only LLW already in a liqud state.

If this alternative is implemented for either liquid or all LLW, development of the following should be considered.

o Methods of organic complexing of the waste to lessen the need for pretreatment of the subsurface formation with buffering solutions.

- Methods of obtaining the necessary subsurface data for evaluating the disposal formation with minimal or no exploratory drilling. Techniques being investigated include high resolution seismic, acoustic, electric, and electromagnetic methods (12).

Data will be required on the expected integrity of the borehole seals for the time required for LLW isolation.

\subsubsection{Related Investigations}

Two previous studies of alternative methods of disposal of radioactive waste have discussed this alternative. One of these reviews which emphasized HLW disposal (105) concluded that, although the technology needed to use this alternative is available and had been investigated for tritiated water disposal, its use with liquids containing long-lived or high levels of radioactivity had yet to be evaluated. The other review which screened alternative methods of LLW disposal (66) concluded that the general injection concept is feasible for liquid effluents and the liquid fractions of LLW, but, for the bulk of LLW which is solid, the liquefaction required and the dispersive nature of the disposal concept make injection unfeasible.

Deep well injection for waste disposal has been recently investigated by Trevorrow and co-workers at Argonne National Laboratory (98, 99), by Spitsyn and co-workers of the U.S.S.R. State Commission on the Use of Atomic Energy (87), by Louis R. Reeder and Associates in a contract study for EPA (79) and 
by Kuhn and co-workers (61) of the Federal Republic of Germany. It is also one of the alternatives considered in the Draft Environmental Statement for the Management of Commercially Generated Radioactive Waste (101). A discussion of these investigations follows.

Trevorrow's investigation considered deep well injection of low level aqueous nuclear fuel reprocessing waste. The requirements imposed by the volume; the chemical, physical, and biological nature of the waste; and design, operation, and monitoring considerations were considered in the investigation. His conclusions were: 1) deep well injection should be as applicable to LLW as it has been applicable with apparent success to chemical wastes; 2) the areas of the US most likely to have suitable geologic conditions for deep well injection are the sedimentary basins. The total area of these basins is large, but substantial effort would be required to choose a favorable site; 3) the most important environmental impacts that could occur are degradation of high quality groundwater, contamination of resources, and the stimulation of earthquakes. The worst case contamination of potable water by the normal low level aqueous waste from a reprocessing plant handling 5 metric tons of uranium per day has the capacity to expose 7,000 persons to water contaminated to the Public Health Service nitrate limit for drinking water and the capacity to cause a population dose of $3 \times 10^{5}$ man-rem/year; 4) legal and regulatory constraints may be the most formidable barrier to the application of deep well injection to the disposal of low level aqueous waste.

Spitsyn reported on the existing U.S.S.R. practice of disposing of low level liquid radioactive waste by deep well injection. As of $1976,2 \times 10^{6}$ cubic meters of wastes with a total activity of $95 \times 10^{6}$ curies had been disposed of in their Niiar reservoir. The wastes had spread out to 400 meters from the injection point. Gas releases from the injection formation were less than expected and were nonradioactive. The investigation is continuing, but Spitsyn concluded that their observations had confirmed the safety and economy of disposing of wastes with a specific activity of up to 25 curies/liter by deep well injection. 
The Louis R. Reeder and Associates Study for the EPA reviewed deep well injection of hazardous, nonradioactive waste. A number of their conclusions are pertinent to disposal of LLW by deep well injection. These include:

1) Sufficient geologic data are available to prepare comprehensive feasibility studies covering all geologic aspects except salt water aquifer hydrology; 2) Aquifers with heavy brines or brackish water with less than 10,000 ppm of dissolved solids should not be considered as injection candidates because they are potential resources; 3) Deep well injection systems of nearly all types of industrial waste are a safe method of handling the wastes if the systems are properly located, designed, operated, managed, and regulated. Almost all operational failures in the past can be attributed to either not using available geological data or proven engineering design and completion practices; 4) Present monitoring techniques are adequate to detect waste passage but ineffective for continuous tracking of waste movement;

5) Reservoir modeling in its present state of the art is not a useful predictive tool.

Kuhn reported on preparations for test injections of tritium into an exploited oil lens near the Karlsruhe Nuclear Research Centre in the Federal Republic of Germany. A license for the test injection is expected this year.

Preparations are based on extensive German experience with deep injections by the oil, potash, and chemical industries.

The use of deep well injection is also being considered as one of the alternatives in the Draft Environmental Statement for the Management of Commercially Generated Radioactive Waste (101). Since it is not considered one of the nearer term alternatives for the disposal of HLW, only some feasibility and preliminary design work has been recommended (52). Consequently, the main benefit from the HLW program that would be useful if this alternative were implemented for LLW would be sharing the borehole and repository sealing technology being investigated for other higher priority HLW alternatives. 


\subsection{DISPOSAL IN HYDROFRACTURED STRATA}

\subsubsection{Description and Application}

This alternative is similar to deep well injection (see Section 3.6) in that both techniques use wells to inject liquid waste into an underground formation. The main differences are in the techniques. In disposal using hydrofractured strata, the waste is mixed with grout which eventually hardens. In deep well injection, the waste remains in the liquid form in which it is injected. In hydrofracturing, fluid is injected under pressure exceeding in situ rock strength in order to fracture a suitable geological strata. In deep well injection, the injected fluid only has to overcome the hydrostatic pressure in the disposal formation.

Hydrofracture is performed by injecting a fluid containing a gel and a material such as silica sand that will prop the fractured strata. To prepare for an injection of waste, a solution containing a gel-breaking agent is pumped at high pressure and drained out of the formation, leaving most of the volume of the fractured strata available for waste injection. The waste is mixed with a grout and injected into the fractured strata. The grout-waste mixture hardens leaving the wastes fixed in the geological strata. Subsequent injections would each be handled similarly but would be at different elevations in the formation. The overall result would be a series of very thin horizontal sheets in the geological formation, each containing the waste from a single injection (106). Figure 3-5 illustrates this concept.

For the hydrofracture technique to be successful, the geologic strata should be of low permeability and should readily split along horizontal planes by the induced hydraulic pressure. Horizontal fracturing is necessary, because vertical fractures could provide paths to the biosphere for waste leached out of the strata. Depending upon principal stress orientations, the use of hydrofracture pressures less than the overburden pressure could result in vertical fractures for rocks of relatively low tensile strength. The possibility is also present that existing vertical fractures of minor extent could become major fractures or even faults in response to induced fracturing. Hydrofracture pressures above the overburden pressure could result in vertical 


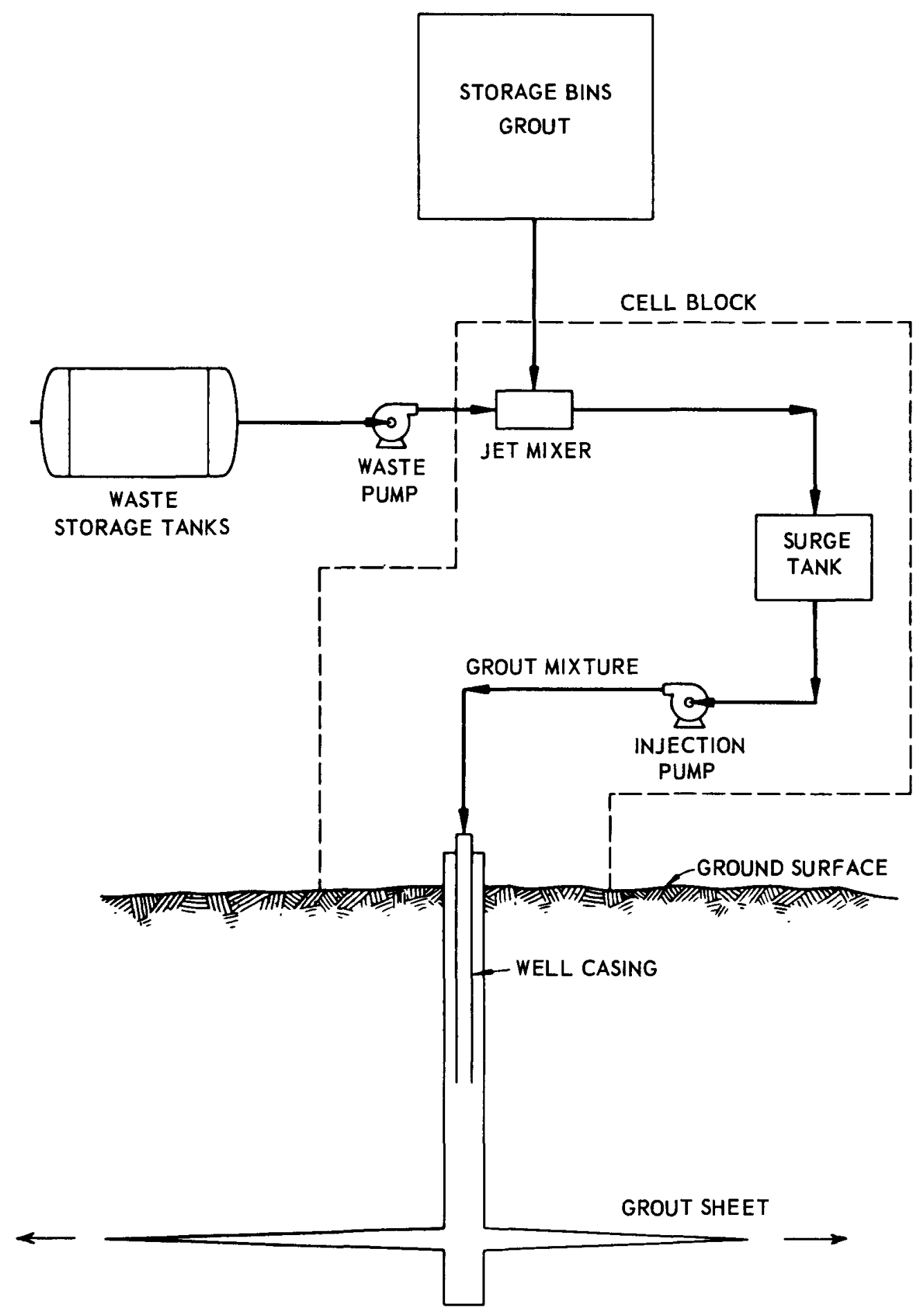

WELL AND FRACTURE

FIGURE 3-5

HYDROFRACTURING AND INJECTION

(FROM ORNL DRAWING NO. 68-14501R) 
and/or horizontal fracturing depending on the in situ state of stress and degree of anisotropy of the strata. By selecting relatively undeformed geological strata, such as flat-lying shale in which horizontal fractures predominate, vertical fracturing can be minimized (106).

Waste isolation is dependent upon the disposal formation being remote from man-made and natural events, impermeable, and characterized by minimal stress conditions.

Hydrofractured strata could accommodate liquid wastes and those wastes that could be converted to a readily injectable form (slurry).

The advantages of this concept include:

- A high degree of isolation and protection from natural and man-made events are possible.

- The technology exists to implement this technique for liquid wastes.

- There is good protection against deliberate and inadvertent contact.

- The disposal site can be released at the end of its operational life for most uses not involving drilling or excavating to the range of depths used for waste emplacement.

The disadvantages of this concept include:

- Higher costs than shallow land burial would be required during the operational life of the disposal site. Comparison of long term costs is dependent on the extent to which remedial measures might be necessary for each disposal method.

- The emplaced waste is irretrievable. 
- Sorption barriers and other engineered barriers other than those incorporated in the grout cannot readily be emplaced around the waste.

o The forms of wastes that can be disposed of are restricted to liquids and other readily injectable forms.

o The stimulation of seismic activity as a result of the hydrofracture process is possible $(101,106)$.

\subsubsection{Equipment and Facility Requirements}

Hydrofracture can only be used when liquid or slurry waste is not shipped across Federal or interstate roadways or land. Existing regulations require that LLW be encapsulated in a form that meets solid monolith criteria. The discussion that follows assumes that the waste is generated, collected, processed, and disposed of by hydrofracture without leaving the nuclear facility site. It is also assumed that injection and observation wells are drilled prior to the initial operation of the hydrofracture facility for waste disposal.

- Waste Receipt and Storage - Liquids

Liquid waste would be forwarded to a hydrofracture facility tank "farm". The tank farm would be designed to hold sufficient quantities of waste for placement in a cost effective manner. Prior to injection, the chemistry, activity, and isotopic content of each tank would be determined by monitoring and/or sampling.

- Waste Receipt and Storage - Solids

Trash and other solid waste would have to be prepared to be injected as a slurry. Trash would be shredded and/or granulated to form pellets. Metals could be melted and flash-cooled to produce granulated ore products, or they could be cryogenically crushed. Sophisticated handling techniques would be required to prepare the solid wastes for slurry application. 
Once the liquid or slurry waste is collected and readied for injection, the volume, activity, and isotopic content of each injection would be logged. The grout mixtures and strata location for each injection would also' e documented.

The gel and silica fluid would be injected to fracture and prop the horizontal formation below the surface. The stored waste would be mixed with the grout plus additives and injected.

\subsubsection{Unusual Operational or Maintenance Requirements}

Provisions for monitoring induced seismic activity, increases in formation permeability, grout sheet orientation and extent, and groundwater quality would be required to assure the continued integrity of the disposal formation. This could be accomplished by using conventional seismic monitoring equipment and appropriately instrumented observation wells.

\subsubsection{Geologic/Environmental Parameters}

The geologic and environmental parameter for disposal in hydrofractured strata are generally as discussed in Section 3.5.4. However, the choice of isolation media for this concept is limited to rock formations that have high ion-exchange capacities and are: 1) largely homogeneous; 2) horizontally or near horizontally bedded; 4) structurally uncomplicated; 5) thick; 6) impervious; and 7) characterized by low in situ stresses.

A high ion-exchange capacity would significantly delay migration of radionuclides leached from the injected grout sheet. Horizontality increases the probability that the hydrofracture and subsequent grout sheet will maintain a relatively horizontal attitude, which would most likely be incident to the bedding plane. Argillaceous rock, such as shale, claystone and 
argillite, are the most likely candidates for the host rock, primarily because of their high sorptive capacities and low permeabilities. Crystalline rocks are not likely to be considered as isolation media because they tend to be pervaded by vertical and inclined fractures. Carbonate strata are excluded as host rock, owing to their inherent tendency to have undergone dissolution resulting in irregular and usually unpredictable, solution channels and enlarged fracture openings capable of transmitting groundwater.

In situ stress is particularly important for this disposal alternative. Under optimum conditions, isotropic stresses are desirable. Alternatively, the minimum principal stress should be oriented vertically, so that induced fracturing will be oriented horizontally, parallel to flat-lying strata. Shale formation are known to fracture horizontally by this method to a depth of 500 to 1,000 meters (101). However, shale as well as other rock types have been routinely hydrofractured to depths considerably deeper than 1,000 meters to stimulate enhanced hydrocarbon recovery.

Hydrofracture has a tendency to stimulate seismic activity in regions under a high state of stresses (101). However, this potential can be avoided by proper injection techniques and site selection for the latter. Tectonically unstable and seismically active regions should be excluded.

It has been estimated that 30 to 35 percent of the continental U.S. is underlaid by shale that may be suitable for disposal by hydrofracture. Nonetheless, comparatively few of these areas are underlain by structurally uncomplicated, flat-lying, unfractured shale of sufficient thickness capable of storing a significantly large volume of LLW. This disposal technique require areas where containment will be assured, requiring appropriate thicknesses, lateral extent and deformational properties.

\subsubsection{Information/Technology Development Requirements}

Information is available from the pilot plant at the Oak Ridge National Laboratory (ORNL), which has used hydrofracture to dispose of liquid, intermediate level wastes for a number of years. For this alternative to have 
general applicability to LLW, processes would have to be developed (or existing processes such as pelletization would have to be adapted) to easily convert the various LLW forms into liquids or slurries that could be mixed with grout and injected into hydrofractured strata. Changes may be required in the form in which wastes are shipped to disposal sites and, thus, in existing waste transportation regulations. Without this development, the hydrofracture concept would be useful in specialized situations (such as at ORNL) but would not have general applicability to LLW disposal.

Data will be required on the expected integrity of the borehole seals that will be used for injection, monitoring, observation, and exploratory wells when the disposal facility is decommissioned.

\subsubsection{Related Investigations}

Two previous studies of alternative methods of disposal of radioactive waste have discussed this alternative. One of these reviews which emphasized HLW disposal (105) concluded that the primary safety concern associated with the use of hydrofracture for radioactive waste disposal is the integrity of long term containment. This concern was apparently based on the lack of data on long term containment of industrial waste disposed of by hydrofracturing and containment problems at two industrial hydrofracture sites from induced seismic activity.

The other review which screened alternative methods of LLW disposal (66) concluded that: 1) comparatively few areas may be thick enough to contain large volumes of low level waste; 2) the concept would require extensive surface handling facilities for liquefaction of solid waste; 3 ) the concept would not provide definite containment; 4) the concept is not a workable alternative for solid low level wastes. No supporting data was provided for these conclusions.

Hydrofracture for the disposal of radioactive waste has been studied by ORNL for intermediate level waste on-site $(106,114)$ and by Acres American, Inc. for disposal of HLW at West Valley, N.Y. (1). Disposal of radioactive waste 
in hydrofractured strata is also one of the alternatives considered in the Draft Environmental Impact Statement for the Management of Commercially Generated Radioactive Waste (101). A discussion of these studies follows.

ORNL has used hydrofracture since 1966 to dispose of intermediate level waste (106, 114). The ORNL disposal method features: 1) the use of an isolated geological formation with a high ion exchange capacity and low permeability, 2) relative ease of creating only horizontal fractures, and 3) the use of a grout that results in a monolithic sheet in the fractured strata. Various observations to check for induced seismic activity, surface uplift, increases in permeability, ground water movement, and orientation and location of the grout sheets have all shown the disposal method to be a satisfactory process for isolating the intermediate level waste at ORNL. The processes and equipment used in the ORNL hydrofracture operation have been developed specifically for the type of waste at ORNL. However, there is no apparent technical reason that the methods used at ORNL could not be adapted to accommodate other waste forms at other locations.

In another study, Acres American, Inc. investigated the technical feasibility of using hydrofracture for disposal of high level radioactive wastes at the Nuclear Fuel Services site at West Valley, New York (1). Hydraulic fracturing experiments were conducted at the site by the USGS and ORNL from 1969 to 1971, including an actual hydrofracture of one of the test" boreholes drilled at a depth of 500 meters. However, no waste has been injected to date at the site.

Even with this data, the actual amount of site information is limited at West Valley. Therefore, to a large extent, analytical methods and extrapolation of regional data to the site were used in addition to the available site data in the study. Another source of information used extensively in the study was the previous work performed at ORNL.

The ultimate goal of the disposal project at West Valley was to inject over a two to three year period 3,000,000 gallons of liquid waste and grout with an activity level of approximately $8 \mathrm{Ci} /$ gallon and transuranics $>20 \mathrm{nCi}$ per gram. 
The report concluded that it appears technically feasible to use hydrofracture techniques at the West Valley location. However, a detailed site program will be required before actual implementation of the plan could begin. Two other potential problems would also have to be resolved before the program could be started:

o Conflict with natural gas and water supplies in the area.

o Potential adverse effects of a deep buried valley filled with glacial sediments on the local capability to produce horizontal fracturing.

Disposal of HLW in hydrofractured strata is one of the alternatives considered in the Draft Environmental Impact Statement on the Management of Commercially Generated Radioactive Waste. However, this alternative was not considered one of the nearer term approaches by the Interagency Review Group. It would, at most, receive funding to allow some feasibility and preliminary design work to proceed if the recommendations of the Interagency Review Group are followed (52). Consequently, borehole sealing technology and site-specific geologic data from higher priority portions of the HLW program would be useful if hydrofracture were implemented as part of the LLW program.

\subsection{DISPOSAL IN CAVITIES}

\subsubsection{Description and Application}

Disposal in cavities involves emplacing LLW in a cavity in an appropriate geological formation (Figure 3-6). The cavity could be a natural cavern, a conventionally mined room and pillar or tunnel repository, a solution mined cavity in salt strata, a cavity formed by an explosion, or an abandoned mine. Containment of waste is dependent upon the stability of the geological formation and its isolation from human activities, natural events, and significant groundwater flow. All forms of LLW could be disposed of in suitably located cavities, although extensive use of methods to reduce waste volumes may be economically desirable. 


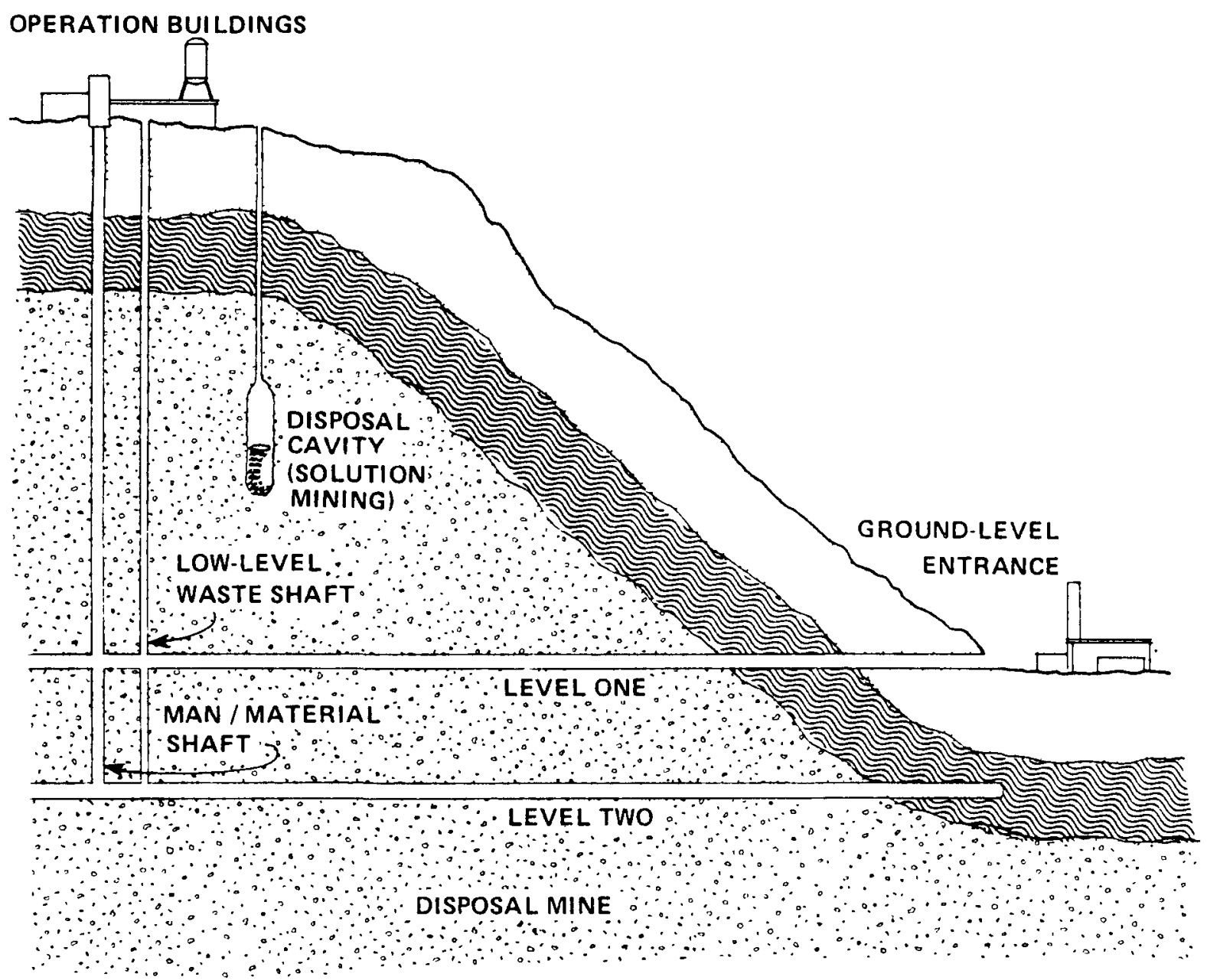

FIGURE 3-6

MINED CAVITY FOR RADIOACTIVE WASTE (67) 
The advantages of this concept include:

o A high degree of isolation and protection from natural events is possible.

o Mining technology exists to implement this alternative.

o There is good protection against deliberate and inadvertent contact.

- Retrievability is possible for many of the types of cavities considered. For some rock types, such as crystalline rock, the retrievability period could be extended as desired. For others, such as salt, retrievability would be possible only for some initial time because of salt's plastic deformation characteristics.

- Sorption barriers and other engineered barriers could readily be accommodated.

o The disposal site could be released at the end of its operational life for most uses not involving drilling or excavating to the range of depths used for waste emplacement.

o The concept has been extensively studied. The results from the HLW disposal programs of a number of countries could be used, since mined repositories are the preferred choice of most countries investigating HLW disposal. The results of the German LLW disposal program which utilizes abandoned mines, would also be valuable (see Section 3.8.6).

o Disposal of HLW and LLW in the same formation is possible.

The disadvantages of this concept include:

o Higher initial costs than shallow land burial would be required. Comparison of long term costs with costs expected for shallow land burial is dependent on what remedial measures may be necessary for each alternative during the period the waste is hazardous. 
For natural cavities, there may be considerable uncertainty regarding their extent and geometry.

o For abandoned mines, previous blasting and drilling may have compromised the isolation integrity of the enclosing rock mass.

\subsubsection{Equipment and Facility Requirements}

A surface storage facility similar to that discussed in Section 3.2.2 for intermediate depth burial and in Section 3.4.2 for disposal in drilled holes would be required. The facility would include the capability of unloading waste containers and providing temporary storage for them. Prior to transfer to the repository, the characteristics of the waste and its disposal location would be documented. Waste could be transported to the disposal areas of the repository by a hoist for a room and pillar repository or by tracked vehicles for a tunnel. Conventional materials handling equipment could be used to unload the hoist or tracked vehicle and emplace the waste.

Surface facilities would also be required for ventilating the repository during operation and for supporting underground mining or tunneling for additional disposal areas. Conventional underground mining or tunneling equipment could be used for additional excavation requirements. Provisions would be needed for surface storage of mined materials (101).

\subsubsection{Unusual Operational or Maintenance Requirements}

Protection of the mine shaft or tunnel entrance from infiltration of water would be required during its operational life until the shaft or tunnel was sealed. Protection could be provided via weather enclosures, diversion ditches, etc. In addition, this alternative has the operational and maintenance requirements that are normally associated with underground mining. 


\subsubsection{Environmental/Geological Parameters}

The important factors which affect isolation in cavities and must be considered in site selection are: rock mass, physicochemical and engineering properties, surface and ground water occurrence and flow characteristics, structural setting, seismicity, and the effects of mining operations. These elements should be considered in the context of the site, local, and regional settings to a depth and lateral extent dictated by previous reconnaissance and boring data.

Several isolation media may be considered provided they are: 1) homogenous, 2) devoid of discontinuities, especially open fractures, 3) structurally uncomplicated, 4) dry, and 5) impervious. The formations which merit investigation include salt, granite, shale, basalt, and tuff. Groundwater may have attacked and dissolved carbonate rocks, so they are generally unsuitable candidates as isolation media. The uncertainties of groundwater flow through carbonate rock are significant. Each medium must be evaluated on the basis of specific host rock physicochemical and engineering properties as well as site conditions .

A potential exists for fractures to pervade crystalline rocks such as granite and basalt; therefore, site exploration and in situ stress measurements must be conducted to determine the long term stability of such formations. Although the host rocks may be relatively impervious with respect to hydraulic flow through pore space, secondary conductivity through jointing must be investigated.

Isolation within a suitable rock mass could be achieved down to 6,000 meters (67). Therefore, regions characterized by an unusually high geothermal gradient should be avoided as discussed in Section 3.4.4. Rocks with existing or potential economic worth should not be considered, because nearby mineral and hydrocarbon extraction could alter groundwater conditions and open or enlarge fractures. Most artificial cavities created by mineral or hydrocarbon extraction are probably unsuitable because of fracturing induced by mining operations. Tectonic stability and the absence of seismic activity are essential to ensure isolation. 
Salt has been the major host rock considered for this concept (101). This is undoubtedly attributable to its self-healing characteristics associated with plastic deformation, high thermal conductivity, and the absence of substantial groundwater infiltration. Argillaceous rocks such as shale, claystone, and argillite are now being considered as host rock because of their plastic deformation properties in addition to their relatively high ion-exchange capacity and adsorption properties which enhance the retardation of radionuclide migration.

Climatic conditions will affect groundwater conditions such that generally arid regions will have a deep water table, whereas those with moderate to high mean annual rainfall normally will be shallower. Some direct recharge should be expected in either case; therefore, site dependent infiltration and percolation rates should be investigated for all forms of disposal cavities.

\subsubsection{Information/Technology Development Requirements}

This alternative would use conventional surface facilities and equipment as well as conventional mining or tunneling equipment. Consequently, no new technology development is required for its implementation. However, if this alternative is chosen it would be desirable to investigate the development of methods and instrumentation that would make it possible to determine in situ bulk rock characteristics without the extensive core drilling that current techniques require. Methods being investigated include high resolution seismic, acoustic, electric, and electromagnetic techniques, such as short pulse radar and continuous wave interferometry (12).

Data will be required on the expected integrity of the seals for the ventilation and access shafts and for the exploratory boreholes.

\subsubsection{Related Investigations}

Three previous reviews of alternative methods of disposal of radioactive waste have discussed this alternative. One of these reviews which emphasized HLW (105) discussed considerations for both conventionally mined and solution 
mined cavities. No insurmountable problems were identified for conventionally mined repositories. Potential difficulties for solution mined cavities are long term stability of the void created within the salt strata by the extraction process and disposal of the brine solution remaining within the void.

The second review $(66,67)$ screened the various alternatives for disposal of LLW and selected a few alternatives considered feasible for more detailed evaluation. Disposal in mined cavities was considered a feasible alternative. With the evaluation criteria and weighting scheme used, it compared favorably with disposal in engineered facilities and ocean disposal but unfavorably with improvements to present shallow land burial practices and intermediate depth burial.

The third review which evaluated selected alternatives for LLW disposal (111, 112 , 113) considered the use of abandoned mines, new mines, natural caverns, and ancient burial techniques. Their conclusions include: 1) most abandoned mines have serious hydrological, geostructural, and chemical problems; 2) dry caverns outside of karst regions with integrated subsurface drainage and excavation of new mines in tectonically and chemically stable areas deserve further consideration; 3 ) the history of ancient burial techniques indicates that more consideration should be given to the possibility of future human intrusion of decommissioned repositories.

In addition to these reviews, there are very active and extensive investigations for the use of cavities for HLW disposal (and in some cases LLW) being conducted by the U.S., Canada, Japan, a number of European countries, and various international organizations $(38,41)$. Because of the large volume of published material available for this alternative, only selected highlights are discussed below. repository sites and develop data and technology to use those sites for isolation of defense and commercially generated HLW (9, 10, 27, 103, 104). Summaries of the current U.S. information base on mined 
repositories is given in References 53, 101, 102, and 103. A full scale review of the overall U.S. radioactive waste management program was recently conducted by representatives of applicable Federal agencies (Interagency Review Group). The direction of the U.S. program will probably be based on the recommendations resulting from this review. Key recommendations relevant to the present discussion include: 1) near term program activities should be based on the assumption that the first Federal disposal facilities will be mined repositories; 2) research and development and detailed site-specific characterization work should include a variety of geologic media and begin immediately; 3 ) construction of a repository should proceed on a stepwise, technically conservative basis and should permit retrievability for some initial time period; 4) a systems approach should be used to select the geologic environment, repository site, and waste form; 5) long term isolation can only be assessed through analytical models; and 6) the effects of future human activities should be evaluated more carefully.

o Canada - Canada's HLW disposal program is concentrating on disposal in crystalline rock formations of the Canadian Shield (42). The program includes concept verification, site selection, construction, and operation of a demonstration facility. Disposal of low, intermediate, and high level waste in a single shared facility is the preferred option (17). By late 1981, the plutons (large masses of coarse grained crystalline rock) in the Canadian Shield which will be technically suitable for a waste disposal facility will be identified, and sufficient data will be available to assess the environmental impact of such a facility. Once the results from the concept verification phase are available, site selection will begin. Construction and operation of a demonstration facility at the selected site is not expected until the late 1980s. If operation of the demonstration facility is successful, it will either be expanded or a commercial facility will be built at another location. This decision is not expected before the end of the century.

Several types of packaging of the waste for the repository are being considered. One involves the use of a corrosion-resistant metal as the major barrier to the release of radioactive material. Others include 
encapsulation in metals or ceramic with metal matrixing and the incorporation of retardants. Investigations are also underway on backfill and overpack (buffer) materials which can retard water infiltration, adjust the chemistry of the water which does infiltrate, and act as a sorption barrier for radionuclides leached from the waste. The reference material, at this time, is a sand-bentonite mixture, but others are being considered.

Sweden - The top priority that the Swedish waste disposal program has received is the result of a Swedish law passed in April 1977, which stipulated that new nuclear plants could not be put in operation unless the plant owners could show that their radioactive waste could be disposed of in a completely safe way $(39,40)$. The program has resulted in the identification of three sites in Precambrian crystalline rock with suitable properties for waste disposal. The key factors in the Swedish disposal concept are: 1) a high integrity container for the waste $(20 \mathrm{~cm}$ of copper with lead encased spent fuel or a titanium and lead container enclosing the stainless steel cylinder that contains the vitrified waste); 2) packing of the container in an impervious buffer material (bentonite or a bentonite/quartz sand mixture); 3 ) storage of the containers in stable bedrock with a low groundwater flow; and 4) chemical properties of the groundwater which severely inhibit leaching of the waste. Implementation of repository construction is not expected until the next century.

Sweden is also studying ALMA, a repository at a depth of 50 meters in crystalline rock, for disposal of low and medium level waste (85). In these studies, they have considered the use of several short tunnels, one large cavern, and several deep vertical shafts with cylindrical cross sections. Each of these designs would include a sand-bentonite leakage barrier, and, in the latter two designs, this barrier would be backed up by a concrete wall. They have eliminated the tunnel alternative from their studies because: 1) trucks would be required to transport the waste within the tunnel; 2) the excavated volume is not used efficiently; 
and 3) backfilling would be difficult. The repository design tentatively accepted is a combination of one large cavern and several vertical shaft alternatives.

- Federal Republic of Germany - Germany's radioactive waste disposal program includes the following:

- The Gorleben salt dome will be investigated for possible construction of a waste repository for all of the various classes of waste produced by the German Nuclear "Entsorgungs - Zentrum" (83). The investigations are expected to begin this year and operation of the repository is expected in the early 1990s. Drilling three to seven holes as deep as 2,000 meters is planned to confirm the suitability of the salt domes for non-heat producing waste only. Drilling more numerous holes to about 250 meters is underway to provide data on the overlying strata, the characteristics of the aquifers, and the chemical and physical characteristics of the groundwater flow. Two shafts will be sunk based on the results of the deep drillings to determine the suitability of the salt dome for all waste, including heat producing waste, and to provide ventilation and access when the repository becomes operational. A model mine has been planned. This plan shows that the repository can be built and operated using current technology. For safety reasons, retrievability is not being considered in the design. The disposal area in the repository will be at a depth of 830 to 900 meters. Shaft sealing will be via the frozen aquifer emplacement technique. LLW will be emplaced using the tumble-down technique developed at Asse, a salt mine used for radioactive waste disposal research and development (see discussion below). Alpha-emitting and medium activity waste with nonretrievable shielding will be remotely stacked. Top loading chambers will be used for medium activity waste using retrievable shielding. Excavated salt will be used to backfill and seal the various disposal chambers. The access and ventilation shafts will be backfilled with salt and sealed with a concrete plug. 
- The Asse salt mine has been used since the mid-1960s for projects related to disposal of low, medium, and high level waste $(2,59$, 62). The mine has several disadvantages that restrict its use as a final repository for HLW. However, these disadvantages are not considered serious enough to limit its use for research and development related to waste disposal or to pose undue risk to the environment for disposal of low and medium level waste. A number of techniques have been used for emplacing the LLW, but, since 1974, the LLW drums have been transported to the disposal chamber by a scoop-tram. They are dumped on a ramp of loose salt and rolled down this ramp without rupturing. The resulting pile of drums is periodically covered with loose salt. This method of emplacement results in lower doses to the disposal personnel, uses more chambers in the mine because of reduced dressing requirements, reduces the possibility of personnel or machinery tracking contamination out of the disposal area, and allows the disposal chamber to be completely filled increasing the ultimate stability of the chamber.

Investigations of improved backfilling material and sealing methods for filled disposal chambers are being pursued.

- The abandoned Konrad iron ore mine is being investigated for disposal of non-alpha emitting, low activity waste (13). The mine is 1,200 meters deep and installations are of modern design. An important geologic feature of the mine is the overlying strata of claystone and marlstones which form a 800 to 1,000 meter uniform geological barrier. These formations are aquitards and are an effective barrier against water inflow from the surface or groundwater horizons. However, even with this barrier, there is still a small inflow of water into the mine. It is believed that part of the water is surface water which was pumped into the mine for operational purposes. The rest is believed to come from the rock formation. Geomechanical, geophysical, and radiological investigations are underway to determine the suitability of the mine for waste disposal. 
- In situ solidification of low and medium level liquid waste in a salt cavern is being investigated as a possible disposal method (56). The liquids would be formed into pellets by adding an inorganic binder; the pellets would be mixed with a cement grout and either inactive or tritium-enriched water and injected into a large salt cavern. The mixture would harden in situ. Investigations being performed to evaluate the concept include specification of waste properties, determination of waste/binder and pellet properties, leachibility of the final product, assessment of the cavern, and studies of engineering features of the concept.

- Other countries - Investigation of waste disposal in cavities by countries other than those listed above include:

- Czechoslovakia - Use of dry, abandoned, limestone mines for disposal of radioactive wastes from isotope users and research institutes (28).

- United Kingdom - Investigation of argillaceous, evaporite, and crystalline rock formations as possible repositories for HLW (33, $38,41)$.

- Italy - Investigations of disposal of HLW in a repository in clay and medium and low level waste in abandoned mines $(41,70)$.

- Belgium - Investigation of a repository in clay for HLW disposal $(36,38,41)$.

- France - Investigation of geological repositories in rock salt and crystalline rock (41).

- Japan - Investigation of granite and zeolite rock formations as potential sites for a geologic repository (41). 
- Austria - Investigation of a proposed site in the Bohemian granitic massif for HLW disposal (50).

If the use of cavities for LLW disposal is an alternative that is chosen for additional investigation as part of the LLW program, the benefits from the various programs considered above would include borehole and shaft sealing technology, emplacement techniques, engineered barrier effectiveness, evaluation methods, and generic data from the various disciplines involved. Additional benefits from the U.S. program are similar to those discussed in Section 3.4.6 for drilled holes and include: 1) review of sites identified and screened during the search for HLW disposal sites as potential LLW disposal sites; 2) use of applicable site-specific data collected at a given site to evaluate its ability to isolate HLW; 3) certain evaluations performed for HLW will not have to be repeated for LLW; 4) possible co-location of HLW and LLW in different areas of the same repository; and 5) possible use of sites inadequate for HLW disposal.

\section{$3.8 \quad$ SEABED DISPOSAL}

\subsubsection{Description and Application}

This concept involves controlled emplacement of waste in either the unconsolidated sediment or basement rock of suitable portions of the ocean floor. Areas such as the abyssal plains, which are stable, have low biological productivity, experience relatively low ocean currents, and contain minimal known mineral resources, are the type of ocean floor areas that are being considered as disposal locations. The waste would be collected at shore locations, loaded in suitably equipped ships, and transported to the disposal location. The waste could either be emplaced in previously prepared holes or, if the ocean floor conditions permitted, emplaced in specialized containers that would penetrate the ocean floor to the desired disposal depth (Figure 3-7). The concept relies on the stability and remoteness of the disposal area and on the confinement characteristics of the sediment at the selected depth for isolation of the waste. 


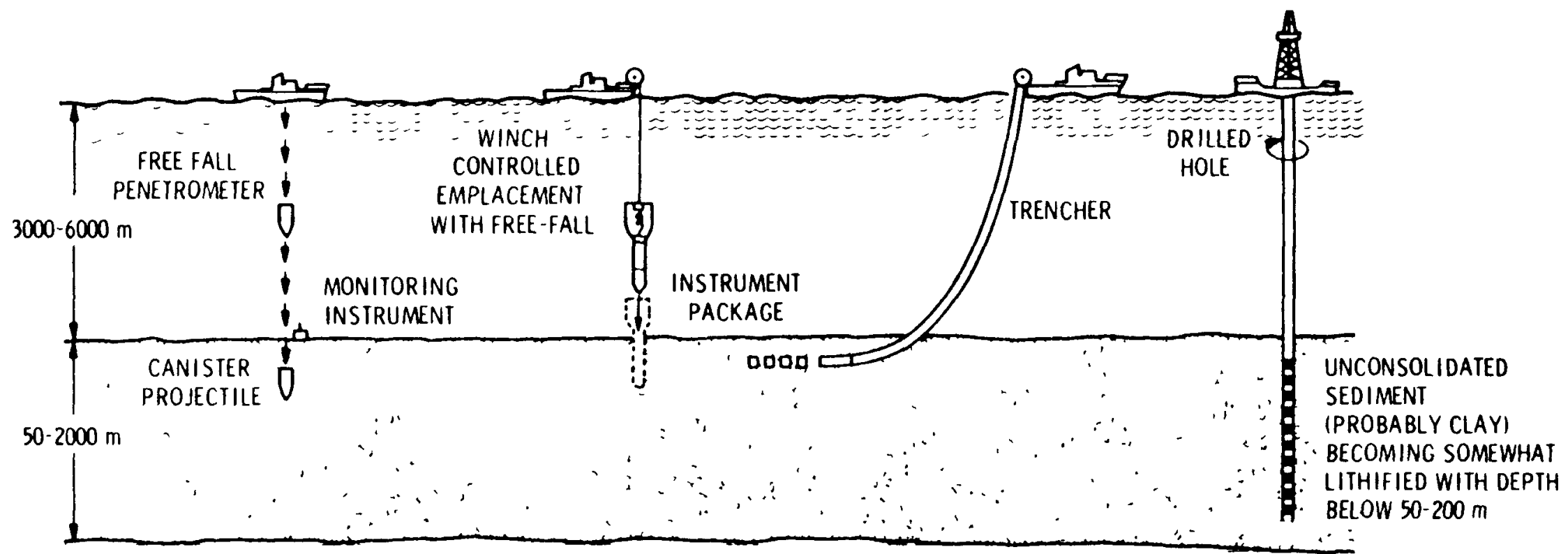

CRUSTAL ROCK (BASALI)

FIGURE 3-7

SEDIMENT EMPLACEMENT CONCEPTS FOR SEABED ISOLATION (101) 
LLW that was solidified and packaged in an appropriate medium could be accommodated. Minimizing waste volumes may be economically desirable.

The advantages of this concept include:

$o$

A high degree of isolation and protection from natural and man-induced events are possible.

- There is good protection against deliberate and inadvertent contact.

o Some degree of retrievability is possible.

o Direct drilling into the disposal area would be the only human activity that would have to be restricted during either the operational or post-operational period of the disposal site.

- The results of the U.S. Ocean Bed Emplacement Program for HLW disposal could be used. This program includes extensive international cooperation and scientific interchange (53).

o Disposal of HLW and LLW in the same formation is possible if this alternative is implemented for HLW disposal.

The disadvantages of this alternative include:

o Higher initial costs than shallow land burial would be required. Comparison of long term costs is dependent on the extent to which remedial measures are required for each disposal method.

- The implementation of this alternative would require an extensive transportation network (ports, loading facilities, ships, etc.) and transportation of the wastes over distances not required for the other alternatives. 
The waste transport, disposal site preparations, and waste emplacement would occur in a less controlled environment than any of the other alternatives.

- Less is known about the ocean floor properties in the areas of interest for waste disposal than is known about the land areas and geological formations used in the other alternatives $(3,53,101)$.

o Monitoring to detect leaks from the emplaced waste would be difficult.

o International consensus on feasibility and safety would be required to implement this alternative.

- Sorption and other engineered barriers other than the waste packaging could not readily be accommodated.

\subsubsection{Equipment and Facility Requirements}

Two types of facilities are required for seabed disposal. One is a land based receiving area and the other is either an off-shore platform or a ship designed to emplace the waste.

- Land Based Receiving Area

Encapsulated waste could be either temporarily stored at a land based facility or transferred to a transport ship. In either case, the characteristics of the waste would be documented. Wastes stored at the land based receiving area would be readied for transport to the offshore seabed disposal area.

o Ocean-going Transport Vehicle

Conventional barge or ship transport would be used with modifications. The transport vehicle would be modified for shielding, isolation, and materials handling equipment. 
If the waste is emplaced in drilled holes in the seabed, the offshore drilling rig would be similar to those used for oil drilling. If projectile emplacement is used, the transport vehicle would be modified with projectile launch equipment.

o Waste Transfer to Deep Seabed

Whether the encapsulated waste is placed or projected into the bed, the actual location of placement should be detectable and documented. Ocean floor mappings of waste placement would be required.

\subsubsection{Unusual Operational or Maintenance Requirements}

During waste placement, equipment that assures waste integrity must be used. Containers and casks would be required to function under significant hydrostatic pressures.

Maintenance of equipment located off-shore is significantly more difficult than that of comparable land-based equipment. All equipment casks and waste containers would be subject to severe corrosion and encrustation. As a result, tolerance and mechanical clearances would be required to account for these deposits.

Operations would have to be planned so adverse weather conditions, such as hurricanes do not interfere with waste transport or emplacement. Contingency plans would have to be developed to cope with unforseen problems, e.g. sinking of ships transporting the radioactive material, etc.

\subsubsection{Geologic/Environmental Parameters}

The important factors which affect isolation in seabed disposal and must be considered in site selection are: sea floor bathymetry, oceanic sediments and rock mass, their respective physicochemical and engineering properties, ocean current and sea floor characteristics. 
Sea floor sediments and oceanic crustal rock are the containment media considered for this concept, provided they are: fairly homogenous and of sufficient thickness, especially in the case of the sediment layer overlying oceanic bedrock. In addition, each media must be evaluated on the basis of specific physicochemical and engineering properties as well as site conditions. Tectonically stable conditions are essential to assure isolation. Climatic conditions must be considered also; the scouring action caused by turbidity currents traveling along the ocean floor could uncover wastes buried in shallow, unconsolidated sediments.

The best ocean floor sites may be in the abyssal plains which are stable and relatively remote from the continental rises down which sediments slump periodically from the relatively shallow continental shelves. Nonetheless, there is much uncertainity regarding ocean floor processes which might compromise the integrity of waste isolation.

Sea floor sediments may be considered as a confinement medium. These sediments are self healing (plastic), impervious, and possess excellent ion-exchange capacities. Radionuclides could migrate by hydraulic flow within these sediments; however, the adsorptive capabilities of the sediments will assist in retarding this process. Molecular diffusion would be the most probable means of radionuclide movement beyond the disposal site, assuming the absence of large fractures.

\subsubsection{Information/Technology Development Requirements}

State of the art equipment exists for drilling holes in the ocean floor, emplacing small objects into ocean sediments using a penetrometer, and remotely operating machinery on the ocean floor. However, in order to use this equipment for waste emplacement, additional developmental work will probably be required. Equipment for retrieval of objects from the ocean floor also exists and could be adapted with some development for use in retrieving waste packages resulting from an accident during transport or emplacement of the waste. The other equipment required for this alternative is readily available and would not require additional development. 
The major information requirement for this alternative is sufficient data on the physical, chemical, geological, and biological characteristics and processes affecting disposal to make quantitative risk assessment possible. Data will also be required on the expected integrity of waste containers. If the waste is emplaced in holes drilled in the ocean floor, data will be needed on the expected integrity of the seals for these holes during the time required for LLW isolation.

\subsubsection{Related Investigations}

Two previous studies of alternative disposal methods for radioactive waste have considered this alternative. One of these reviews which emphasized HLW disposal (105) concluded: 1) the engineering capabilities for carrying out oceanic operations are far ahead of the research required to identify the critical emplacement parameters and breachment modes; 2) emplacement of waste canisters well below the ocean floor appears to provide a set of barriers to the release of radionuclides; 3 ) there are regions of the oceans that appear to be suitable for study as disposal locations (midplate/midgyre regions of the major oceanic basins); 4) although insufficient data is available to assess technical feasibility, enough is known to define the questions and the systematic interdisciplinary effort required to answer them; and 5) no insurmountable technical barriers for this disposal concept have been identified.

The other review which evaluated alternative methods of LLW disposal (67) concluded that seabed disposal of LLW was a feasible alternative, but, with the evaluation criteria and weighting scheme used, it was one of the least favorable alternatives compared with the other alternatives studied (improvements to shallow land burial, intermediate depth burial, disposal in cavities, disposal in engineered facilities, and ocean disposal).

Both the technical and nontechnical issues related to the use of the seabed for HLW disposal are being studied actively by a number of countries as evidenced by the following: 
An International Seabed Working Group, which includes the U.S., United Kingdom, France, Japan, and Canada, has been organized under the auspices of the Nuclear Energy Agency. The goals of the working group include coordination of research; exchange of data, testing procedures, and samples; and sharing of facilities and equipment (3).

- International workshops on seabed disposal of HLW have been held annually since 1976. Participation in these workshops has included not only members of the International Seabed Working Group but a number of otner nations (48).

The Commission of the European Communities has suggested in their recent Proposal for a Second Five Year Programme (1980-84) on Radioactive Waste Management and Storage that disposal in seabed geological formations be studied (21). Their proposed program includes a preliminary assessment of the following design and engineering problems associated with disposal: identification and evaluation of critical emplacement parameters and container failure and safety assessments of waste isolation properties.

- Seabed disposal is one of the alternatives the U.S. is considering as noted in the Draft Environmental Impact Statement for the Management of Commercially Generated Radioactive Waste (101).

The U.S. has underway a three-phase program for investigating seabed disposal of HLW. The end dates for the three phases are 1983, 1990, and 1995, respectively. Each succeeding phase will continue only if nothing is identified in the previous phase to eliminate the concept. The near term objectives of Phase 1 are assessing the environmental and technical feasibility of HLW disposal in geological formations below suitable portions of the ocean floor and developing a capability of assessing ocean disposal programs developed by other nations. Phase 2 will assess the engineering aspects of HLW emplacement. Phase 3 will attempt to demonstrate the seabed disposal concept through semiroutine emplacement $(3,53)$. The funding for the program is expected to continue since the 
IRG has recommended the concept for funding support so that it can be adequately evaluated as a potential competitor to mined repositories (52).

- Deese has extensively studied the political, legal, institutional, and ethical issues of seabed disposal of HLW $(25,26)$. His major conclusions include: 1) it is not yet clear whether legal and political obstacles to the use of the seabed can be surmounted, 2) development of sound legal controls cannot be permitted to lag behind advances in science and technology, 3) the total amount of radioactivity from all sources should be controlled so that it will not exceed what the marine environment can tolerate, and 4) the interim legal position that the nation involved in seabed disposal should take is that, if seabed disposal threatens the marine environment, it will be considered dumping as defined in the London convention of 1972. If seabed disposal is adequately demonstrated, it may be suitable for radioactive waste disposal and implemented under the London convention and/or a specifically negotiated international agreement.

If seabed disposal of LLW is an alternative that is chosen for additional investigation as part of the LLW program, there are several ways in which results from the HLW studies discussed above could be useful. The benefits of avoiding duplication in site selection and site-specific data gathering are similar to those discussed in Section 3.8.6 for disposal in cavities. Additional benefits include:

- Evaluation of isolation characteristics - Many of the studies performed to identify and evaluate ocean floor processes affecting isolation will not have to be repeated for LLW.

o Use of HLW sites - Sites evaluated and rejected for HLW disposal may be adequate for LLW disposal. Sites approved for HLW disposal may accommodate LLW disposal at the same location. 
- Waste transport and emplacement - The transportation network and emplacement techniques that will be developed if seabed disposal is used for HLW disposal will probably be readily adaptable to LLW with minor modifications. 
SECTION 4.0

CONCLUSIONS

As a result of this review, certain alternatives appear to have significant advantages and fewer disadvantages than others. However, before selecting the most desirable alternatives for the disposal of LLW, it will be necessary to develop evaluation criteria and reference concepts to perform a detailed comparative evaluation. Even though such an evaluation has not been performed as part of this review, the following comparisons can be made based on the information collected:

- Disposal in cavities is the alternative that has been studied the most extensively and the one that would benefit the most from the results of the near term HLW program. Disposal below the water table using either intermediate depth burial or disposal in drilled holes has been studied the least extensively but definitely merits further investigation. Seabed disposal is being actively studied but is the alternative that is expected to require the most additional study for implementation.

- The alternatives that appear to have the potential to provide the highest degree of protection from unauthorized contact and/or natural events are disposal in cavities and seabed disposal. Upgrade of shallow land burial and disposal in engineered facilities offer the least protection because of their proximity to human activities and natural forces. The isolation provided by any of the alternatives will be a function of the engineered barriers, if any, incorporated in the concept and site-specific properties of actual disposal locations.

o Restrictions on the future use of decommissioned disposal sites would be the greatest for upgrade of shallow land burial and disposal in engineered facilities. Substantially, fewer restrictions would be required for the alternatives with seabed disposal being the least restrictive. 
The only alternatives requiring technology development before they can be implemented are seabed disposal and disposal of non-liquid waste using deep well injection or hydrofractured strata. For the other alternatives there are technological developments that are desirable but are not required for their implementation.

The facilities and equipment required to implement disposal operations would be the greatest for seabed disposal and least for upgrade of shallow land burial and intermediate depth burial. The requirements for the other alternatives are intermediate between these but are not expected to present unusual difficulties in their implementation.

- Seabed disposal is the only alternative whose operation and maintenance requirements are expected to present unusual difficulties.

- The short term cost of all the alternatives are expected to be higher than the costs for present burial practices. However, the long term costs of present burial practicies may be higher since expensive corrective measures and close surveillance have been and will be required for the forseeable future at some burial grounds.

- Retrievability is possible to some degree for all of the alternatives except disposal in hydrofractured strata. Where retrievability is possible, seabed disposal and deep well injection are expected to present the most difficulties and engineered facilities the least. 
SECTION 5.0

\section{BIBLIOGRAPHY}

1. Acres American Incorporated. Injection of radioactive waste by hydraulic fracturing at West Valley, New York; preliminary feasibility study. Buffalo, NY: Argonne National Laboratory; 1978 May; ANL-K78-4238-1 vol. 2 .

2. Albrecht, E.; Breest, H. C. The development of radioactive waste disposal - techniques and the radiation - exposure of the personnel at Asse pilot plant. Post, R. G., ed. Proceedings of the symposium on waste management; 1976 0ct. 3-6; Tucson, AZ: 283-302. CONF. 761020 .

3. Anderson, D. R. Seabed high level waste assessment program.

Albuquerque, NM: Sandia Laboratories; 1978 May 16; SAND 78-0937

(C). $10 \mathrm{p.}, \mathrm{xiv}$.

4. Angino, E. E. High-level and long-lived radioactive waste disposal. Science 198: 885-890; 1977 Dec. 2 .

5. Angino, E. E.; Dreschhoff, G.; Zeller, E. J. Antarctica - a potential international burial area for high-level radioactive waste. Bulletin of the International Association of Engineering Geology no. 14:173-178(1976).

6. Apps, J. A.; Cook, N. G. W.; Witherspoon, P. A. An appraisal of underground radioactive waste disposal in argillaceous and crystalline rocks: some geochemical, geomechanical, and hydrogeological questions. Berkeley, CA: Lawrence Berkeley Laboratory; 1978 June; LBL-7047.

7. Bardet, G. Seven years' experience with storage of solid low- and medium-activity radioactive waste on the surface and in concrete-lined trenches. Proceedings of a symposium on management of radioactive wastes from the nuclear fuel cycle; 1976 Mar. 22-26; Vienna, Austria. Vienna: IAEA; 1976; 2:351-357.

8. Barraclough, J. R.; Robertson, J. B.; Janzer, V. J. Geohydrologic study of a burial site for solid low-level radioactive wastes at the Idaho National Engineering Laboratory. Carter, M. W.; Moghissi, A. A.; Kahn, B., eds. Management of low-level radioactive waste. New York: Pergamon Press; 1979; 2:795-824.

9. Batch, J. M.; Heath, C. A. U.S. program for disposal of radioactive wastes. Columbus, $\mathrm{OH}$ : Battelle Memorial Institute (U.S. DOE). Presented at International symposium on the underground disposal of radioactive wastes; 1979 July 2-6; Otaniemi, Finland; IAEA-SM-243/77. $21 \mathrm{p}$. 
10. Battelle Columbus. National waste terminal storage program: volume 1 technical overview. Columbus, $\mathrm{OH}$ : Battelle office of Nuclear Waste Isolation; 1979 Feb. 16; ONWI-19.

11. Bischof, K.; Pelzer, N.; Rauschning, D. System study radioactive wastes in the Federal Republic of Germany; v.4 The law governing the disposal of radioactive wastes. Hanau, Germany: University of Gottingen (U.S. ERDA); 1977 January; ERDA-tr-307. ix, 120 p.

12. Bredehoeft, J. D.; England, A. W.; Stewart, D. B.; Trask, N. J.; Winograd, I. J. Geologic disposal of high-level radioactive wastes earth-science persepectives. Washington, DC: U.S. Geological Survey; Geological Survey Circular 779. $15 \mathrm{p}$.

13. Brewitz, W.; Loschhorn, V. Geo-scientific investigations in the abandoned iron ore mine KONRAD for a safe disposal of certain radioactive waste categories. Presneted at International symposium on the underground disposal of radioactive wastes; 1979 July 2-6; Otaniemi, Finland; IAEA-SM-243/14. 13 p.

14. Burkholder, H. C. Methods and data for predicting nuclide migration in geologic media. Proceedings of the International symposium on the management of wastes from the LWR fuel cycle; 1976 July 11-16; Denver, C0. U.S. ERDA: 658-666; CONF-76-0701.

15. Carter, T. J.; Mentes, G. A. Ontario hydro waste storage concepts and facilities. Proceedings of the symposium on waste management; 1976 October 3-6; Tucson, AZ; 247-261.

16. Chapman, N.; Gray, D.; Mather, J. Nuclear waste disposal: the geological aspects. New Scientist (London) 78:225-227; 1978 April 27.

17. Charlesworth, D. H. Current development programs for the disposal of low- and intermediate-level radioactive wastes. Chalk River, Ontario: Chalk River Nuclear Laboratories. Presented at Canadian Nuclear Association symposium on the management of radioactive wastes in Canada; 1979 April 10-11; Toronto, Canada. $14 \mathrm{p}$.

18. Cherry, J. A.; Gillham, R. W.; Grisak, G. E.; Lush, D. L. A concept for long-term isolation of solid radioactive waste in fine-grained deposits. Carter, M. W.; Moghissi, A. A.; Kahn, B., eds. Management of low-level radioactive waste. New York: Pergamon Press; 1979: 2:1021-1040.

19. Cherry, J. A.; Grisak, G. E.; Jackson, R. E. Hydrogeological factors in shallow subsurface radioactive waste management in Canada. Presented at Internation conference on land for waste management; 1973 October; Ottawa, Canada. 131-146.

20. James H. Cobbs Engineering. Study of mined storage caverns. Tulsa, OK: U.S. ERDA; 1975 June; ORNL/SUB-75/64509. 4 p. 
21. Commission of the European Communities. Proposal for a second five year programme (1980-84) on radioactive waste management and storage. Brussels: Commission of the European Communities; 1979 March; COM (79) 81 final.

22. Cook, N. G. W. An appraisal of hard rock for potential underground repositories of radioactive wastes. U.S. EPA; 1977 October; LBL-7004. $15 \mathrm{p}$.

23. Cook, N. G. W.; Witherspoon, P. A. Mechanical and thermal design considerations for radioactive waste repositories in hard rock. Berkeley, CA: Lawrence Berkeley Laboratory; 1978 0ct.; LBL-7073. ii, $26 \mathrm{p}$.

24. DeBuchananne, G. D. Geohydrologic considerations in the management of radioactive waste. Nuclear Technology 24:356-361; 1974 Dec.

25. Deese, D. A. Level, political, and institutional implications of the seabed assessment program for radioactive waste disposal. Woods Hole, MA: Woods Hole Oceanographic Institution; CO0 4172-1.

26. Deese, D. A. Nuclear power and radioactive waste: a sub-seabed disposal option? Lexington, MA: Lexington Books; 1978. xvii, 206 p.

27. Deju, R. A. Status report on studies to assess the feasibility of storing nuclear waste in Columbia Plateau basalts. Richland, WA: Rockwell International, Rockwell Hanford Operations. Presented at International symposium on the underground disposal of radioactive wastes; 1979 July 2-6; Otaniemi, Finland; IAEA-SM-243/36 (RHO-BWI-SA-19). 14 p.

28. Dlouhy, Z.; Kortus, J.; Malasek, E.; Marsk, J.; Seliga, M. Disposal of low- and intermediate-level waste in the CSSR: experience and preparation of a repository. Prague: Czechoslovak Atomic Energy Commission. Presented at International symposium on the underground disposal of radioactive wastes; 1979 July 2-6; Otaniemi, Finland; IAEA-SM-243/156. $15 \mathrm{p}$.

29. Duguid, J. 0. Final report on assessment of DOE low-level radioactive solid waste disposal/storage activities. Columbus, $0 \mathrm{H}$ : Battelle Columbus Laboratories. 1977 November 30 ; BMI-1984. iii. 48 p. A $1-40, B 1-9$.

30. Dyne, P. J. Canadian geologic isolation program. Proceedings of the International symposium on the management of wastes from the LWR fuel cycle; 1976 July 11-16; Denver, C0. U.S. ERDA: 601-608; CONF-76-0701.

31. The elimination of radioactive wastes. $L^{\prime}$ actualite Chimique June-July 1977, p. 53-56. OLS-78-144. 
32. Feates, F. S. National policy for underground disposal of radioactive wastes in the United Kingdom. London: Department of the Environment. Presented at International symposium on the underground disposal of radioactive wastes; 1979 July 2-6; Otaniemi, Finland; IAEA-SM-243/30.

33. Feates, F.; Lewis, J. UK looks at geological and ocean disposal. Nuclear Engineering International 23:53-55; 1978 Jan.

34. Federal Register, vol. 39, no. 69, Tuesday, April 9, 1974, p. 12922.

35. Gale, J. E.; Witherspoon, P. A. An approach to the fracture hydrology at Stripa: preliminary results. Berkeley, CA: Lawrence Berkeley Laboratory; 1979 May; LBL-7079/SAC-15. 26 p.

36. Gera, F. Geologic isolation programs in other countries. Proceedings of the International symposium on the management of wastes from the LWR fuel cycle; 1976 July 11-16; Denver, C0: 609-617. CONF-76-0701.

37. Gera, F.; Lenzi, G.; Sensi, L.; Cassano, G. Disposal of long-lived radioactive wastes in Italy. Management of radioactive wastes from the nuclear fuel cycle. Proceedings of a symposium; 1976 Mar. 22-26; Vienna, Austria. Vienns: IAEA; 1976; 2:259-270.

38. Gera, F.; Olivier, J. P. OECD countries pursue geological disposal. Nuclear Engineering International 23:35-37; 1978 Jan.

39. Handling and final storage of unreprocessed spent nuclear fuel. Sweden. Kaernbraens lesaekerhet. (1N1S-MF-4391).

40. Handling of spent nuclear fuel and final storage of vitrified high level reprocessing waste. Vol. 1. Kaernbraenslesaekerhet. Sweden. 1978. (1N1S-MF-4461).

41. Harmon, K. M. Summary of national and international radioactive waste management programs 1979. Richland, WA: Pacific Northwest Laboratory (U.S. DOE); 1979 Mar.; PNL-2941. 69 p.

42. Hatcher, S. R.; Mayman, S. A.; Tomlinson, M. Development of deep underground disposal for Canadian nuclear fuel wastes. Presented at International symposium on the underground disposal of radioactive wastes; 1979 July 2-6; Otaniemi, Finland; IAEA-SM-243/167. 12 p.

43. Heckman, R. A.; Johnson, W. A.; Holdsworth, T. Systems analysis study for waste management criteria. Livemore, CA: Lawrence Livermore Laboratory; 1978 March 1. Presented at Symposium on waste management and fuel cycles; 1978 March 6-8; Tucson, AZ: UCRL-80850. $16 \mathrm{p}$.

44. Heremans, R.; Dejonghe, P.; Willock, J.; Gulinck, M.; Laga, P. Investigations of the possibility of definitive disposal of radioactive wastes in an underground clay formation. Proceedings of the symposium on management of radioactive wastes from the nuclear fuel cycle; 1976 Mar 22-26; Vienna, Austria. Vienna: IAEA; 1976; $2: 245-258$ (OLS-78-466 16) 
45. Hill, J. Radioactive waste management in the United Kingdom. Proceedings of the international symposium on the management of wastes from the LWR fuel cycle; 1976 July 11-16; Denver, CO. U.S. ERDA: 12-17; CONF-76-0701.

46. Hill, M.; Grimwood, P. Nuclear waste disposal: radiological protection aspects. New Scientist (London) 78:1102; 1978 May 11 .

47. Hofmann, R. B. Seismic design considerations for deep geologic repositories. Seattle, WA: Golder Associates. Presented at American Nuclear Society Meeting; Atlanta, GA.

48. Hollister, C. D.; Anderson, D. R.; Talbert, D. M. The first international workshop on seabed disposal of high-level wastes. Proceedings of the International symposium on the management of wastes from the LWR fuel cycle. 1976. July 11-16; Denver, C0: 639-657. CONF-76-0701.

49. Hollister, C. D.; Corliss, B. H.; Anderson, D. R. Submarine geologic disposal of nuclear waste. Presented at International symposium on the underground disposal of radioactive wastes; $1979 \mathrm{July} \mathrm{2-6}$; Otaniemi, Finland; IAEA-SM-243/99.

50. Holzer, H.; Oszuszky, P.; Rudan, P.; Stumpf1, E.; Weber, P. An interdisciplinary geoscientific investigation of a proposed site for highly radioactive waste disposal in Austria. Presented at International symposium on the underground disposal of radioactive wastes; 1979 July 2-6; Otaniemi, Finland; IAEA-SM-243/1. 15 p.

51. Horton, J. H.; Corey, J. C. Storing solid radioactive wastes at the Savannah River Plant. Aiken, SC: E. I. Du Pont de Nemours and Company; U.S. EPA; 1976 June; DP-1366. 44 p.

52. Interagency Review Group on Nuclear Waste Management. Report to the President by the Interagency Review Group on Nuclear Waste Management. 1979 March. TID-29442. 149 p. Appendices.

53. Interagency Review Group on Nuclear Waste Management. Subgroup report on alternative technology strategies for the isolation of nuclear waste. 1978 October; TID-28818 (draft).

54. International Atomic Energy Agency. Site selection factors for repositories solid high-level and alpha-bearing wastes in geological formations. Vienna: IAEA; 1977; Technical Reports Series No. 177 (STI/DOC/10/177). 63 p.

55. Kehnemuyi, M.; Matthews, S. C. Site selection, site investigations and design activities in the USA for nuclear waste repositories in bedded and dome salt formations. Presented at International symposium on the underground disposal of radioactive wastes; 1979 July 2-6; Otaniemi, Finland; IAEA-SM-243/151. 7 p. 
56. Koster, R.; Kraemer, R.; Koeobel, R. Disposal and fixation of mediumand level liquid wastes in salt caverns. Presented at International symposium on the underground disposal of radioactive wastes; 1979 July 2-6; Otaniemi, Finland; IAEA-SM-243/16. 19 p.

57. Koster, R.; Kraemer, R.; Kroebel, R. Project on storage and solidification of MAW and LAW in underground caverns: first progress report. Karlsruhe, Germany: Kernforschungszentrum; 1978 August; OLS-78-488. $60 \mathrm{p}$.

58. Kown, B. T.; Stenzel, R. A.; Hepper, J. A.; Ruby, J. D.; Milligan, R. T. Cost assessment for the emplacement of hazardous materials in a salt mine. Cincinnati, OH: U.S. EPA, Municipal Environmental Research Laboratory; 1977 November; EPA-600/2-77-215. xiii, 184 p.

59. Kuhn, K.; Albrecht, E.; Kolditz, H. et al. Recent results and developments on the disposal of radioactive wastes in the Asse Salt Mine. Proceedings of the symposium on management of radioactive wastes from the nuclear fuel cycle; 1976 Mar. 22-26; Vienna, Austria. Vienna: IAEA; 1976; 287-294.

60. Kuhn, K.; Hamstra, J. Geologic isolation of radioactive wastes in the Federal Republic of Germany and the respective program of the Netherlands. Proceedings of the International symposium on the management of wastes from the LWR fuel cycle; 1976 July 11-16; Denver, CO. U.S. ERDA: 580-600; CONF-76-0701.

61. Kuhn, K.; Randl, R. P.; Rothemeyer, H. The Federal Republic of Germany's program for the disposal of radioactive waste. Presented at International symposium on the underground disposal of radioactive wastes; 1979 July 2-6; Otaniemi, Finland; IAEA-SM-243/95. 22 p.

62. Kuhn, K., Rothemeyer, H. and Salander, C. West Germany gears up for licensing process. Nuclear Engineering International, vol. 23, no. $266,48-53$. Jan. 1978 .

63. Law Engineering Testing Company. Report on Maxey Flats geohydrologic investigation. Marietta, GA: Law Engineering Testing Company. $20 \mathrm{p}$.

64. Lawrence Berkeley Laboratory. Geotechnical assessment and instrumentation needs for nuclear waste isolation in crystalline and argillaceous rocks, symposium proceedings; 1978 July 16-20. Berkeley, CA: Lawrence Berkeley Laboratory; 1979; LBL-7096. ix, 218 p.

65. Lincoln, R. C.; Snyder, A. W. Disposal in continental geologic formations. Proceedings of the international symposium on the management of wastes from the LWR fuel cycle; 1976 July $11-16$; Denver, CO. U.S. ERDA: 621-638; CONF-76-0701.

66. Macbeth, P. J.; Thamer, B. J.; Christensen, D. E.; Wehmann, G. Screening of alternative methods for the disposal of low-level radioactive wastes. Salt Lake City, UT: Ford, Bacon \& Davis Utah Inc. (U.S. NRC); 1978 October; NUREG/CR-0308. 122 p. 
67. Macbeth, P.; Wehmann, G.; Thamer, B.; Card, D. Evaluation of alternative methods for the disposal of low-level radioactive wastes. Salt Lake City, UT: Ford, Bacon \& Davis Utah Inc. (U.S. NRC); 1979 July; NUREG/CR-0680. $168 \mathrm{p}$.

68. McClain, W. C. Earthquake Introduced by Underground Fluid Injection. ORNL-TM-3154. Oak Ridge National Laboratory. Oak Ridge, Tennessee. October 1970.

69. Meyer, G. L. Problems and issues in the ground disposal of low-level radioactive wastes, 1977 . Presented at ASME, USERDA, USEPA, USGS and USNRC symposium on management of low-level radioactive waste; 1977 May 23-27; Atlanta, GA. 25 p.

70. Mittempergher, M. A strategy for the disposal of radioactive wastes in Italy. Rome, Italy: CNEN - Dipartimento Radiazioni e Ricerche di Sicurezza e Protezione. Presented at International symposium on the underground disposal of radioactive wastes; 1979 July 2-6; Otaniemi, Finland; IAEA-SM-243/67. 11 p.

71. National Research Council. Geological criteria for repositories for high-level radioactive wastes. Washington, DC: National Academy of Sciences; 1978 August 3. vii, 19 p.

72. National Research Council. The shallow land burial of low-level radioactively contaminated solid waste. Washington, DC: National Academy of Sciences; 1976. xvii, 150 p.

73. OECD Nuclear Energy Agency. Objectives, concepts and strategies for the management of radioactive waste arising from nuclear power programmes. Paris: OECD; 1977. 174 p.

74. Ohmachi, S. Research and planning on low-level radioactive waste disposal in Japan. Transactions, 2nd Pacific Basin Conference; 1978 Sept.; Tokyo, Japan: 213-214.

75. Orlowski, S.; Girardi, F.; Bresesti, M. C.E.C. program on radioactive waste management disposal and risk assessment. Post, R. G., ed. Proceedings of the symposium on waste management; 1976 0ct. 3-6; Tucson, AZ: 272-282. CONF-761020.

76. Paterson, W.S.B. Radioactive waste disposal in Antarctica: some glaciological aspects. Modern Geology. London: Gordon and Breach Science Publishers Ltd.; 1976;6:37-42.

77. Pusch, R. Highly compacted sodium bentonite for isolating rock-deposited radioactive waste products. Nuclear Technology 45:153--57; 1979 Sept.

78. Redon, A. Waste management French programmes and approaches. Post, R. G., ed. Proceedings of the symposium on waste management; 1976 0ct. 3-6; Tucson, AZ: 229-246. CONF-761020. 
79. Louis R. Reeder and Associates. Review and assessment of deepwell injection of hazardous waste. vol. 1. Tulsa, OK: Cincinnati, OH: U.S. EPA, Municipal Environmental Research Laboratory; 1977 June; EPA-600/2-77-029a. xxviii, 186 p.

80. Reviews of Modern Physics 50 (1): S121-S128; 1978 January.

81. Reynolds Electrical \& Engineering Co., Inc.; U.S. DOE, Nevada Operations Office. An assessment of the Nevada test site for low-level waste management. U.S. DOE; 1978 February; NVO-193. 48 p.

82. Robertson, J. B. Shallow land burial of low-level radioactive wastes in the United States - geohydrologic and nuclide migration studies. Presented at International Symposium on the Underground Disposal of Radioactive Wastes. Otaniemi near Helsinki. 2-6 July 1979. (IAEA-SM-243/152).

83. Rothemeyer, H. Site investigations and conceptual design for the mined repository in the German nuclear "Entsorgungs-Zentrum." Presented at International symposium on the underground disposal of radioactive wastes; 1979 July 2-6. Otaniemi, Finland; IAEA-SM-243/48. 21 p.

84. Royal Commission on Environmental Pollution. Sixth report: nuclear power and the environment. London: Her Majesty's Stationery Office; 1976; 131-164.

85. Rydell, N.; Degerman, 0.; Thegerstrom, C.; Gelin, R.; Cederstrom, M. ALMA - a study of a repository for low- and medium-level waste in a rock cavern. Presented at International symposium on the underground disposal of radioactive wastes; 1979 July 2-6; Otaniemi, Finland; IAEA-SM-243/66.

86. Sousselier, Y. European practices and programs for the management of non-high-level wastes. Proceedings of the International symposium on the management of wastes from the LWR fuel cycle; 1976 July 11-16; Denver, CO: 225-234; CONF-70-0701.

87. Spitsyn, V. I.; Pimenov, M. K.; Balukova, V. D.; Leontichuk, A. S. et al. Basic prerequisites and the practice of using deep water tables for burying liquid radioactive wastes. Proceedings of International conference on nuclear energy and its fuel cycle; 1977 May 2-13; Saltzberg, Austria (IAEA-CN-36/345); ORNL-tr-4390. 20 p.

88. Stearns, Conrad and Schmidt Consulting Engineers, Inc. Study of engineering and water management practices that will minimize the infiltration of precipitation into trenches containing radioactive waste. Long Beach, CA: U.S. EPA; 1977 Sept.; ORP LV-78-5 (PB 283 365). 85 p.

89. Steger, J. G. Burial technology. Carter, M. W.; Moghiss, A. A.; Kahn, B., eds. Management of low-level radioactive waste. New York: Pergamon Press; 1979. 2:665-677. 
90. Stevens, P. R.; DeBuchananne, G. D. (U.S.G.S.) Problems in shallow land disposal of solid low-level radioactive waste in the United States. Bulletin of the International Asso. of Engineering Geology. n. 14, $161-171,1976$.

91. Stone, R. B.; Aamodt, P. L.; Engler, M. R.; Madden, P. Evaluation of hazardous wastes emplacement in mined openings. Cincinnati, OH:

U.S. EPA. Municipal Environmental Research Laboratory; 1975 December; EPA-600/2-75-040. xii, 552 p.

92. Sumner, W. B.; Thomas, L. L. Description of Allied-General Nuclear Services on-site solid waste storage concepts. Carter, M. W.; Moghissi, A. A.; Kahn, B., eds. Management of low-level radioactive waste. New York: Pergamon Press; 1979; 2:659-698.

93. Tammemagi, H. Y. Underground disposal of Canada's nuclear waste. Geoscience Canada 4(2):71-76; 1977 Jan. 27.

94. Tamura, T. et al. Shallow land burial: experience and developments at Oak Ridge National Laboratory. (unpublished).

95. Thompson, W. T. The disposal of solid low-level radioactive waste. Los Alamos Scientific Laboratory; 1978 August; Contract No. N67-5821-C-1. $\mathrm{x}, 1-192$.

96. Tomlinson, M. Canada keeps its disposal options open. Nuclear Engineering International $23: 43-45 ; 1978 \mathrm{Jan}$.

97. Tomlinson, M.; Mayman, S. A.; et al. Management of radioactive wastes from nuclear fuels and power plants in Canada. International conference on nuclear power and its fuel cycle; 1977 May 2-13; Salzburg, Austria; IAEA-CN-36/178. 16 p.

98. Trevorrow, L. E.; Steindler, M. J. Control of environmental impact of low-level aqueous fuel reprocessing wastes by deepwell disposal. Argonne, IL: Argonne National Laboratory. Presented at $71 \mathrm{st}$ annual méeting of the American Institute of Chemical Engineers; 1978 Nov. 12-16; Miami, FL 10 p. +

99. Trevorrow, L. W.; Warner, D. L.; Steindler, M. J. Considerations affecting deepwell disposal of tritium-bearing low-level aqueous waste from nuclear fuel reprocessing plants. Argonne, IL: Argonne National Laboratory; 1977 Mar.; ANL-76-76. xii, 190 p.

100. U.S. Department of Energy. Environmental and other evaluations of alternatives for long-term management of stored INEL transuranic waste. Washington, DC: U.S. DOE; 1979 February; DOE/ET-0081.

101. U.S. Department of Energy. Management of commercially generated radioactive waste, draft environmental impact statement. Washington, DC: U.S. DOE; 1979 April; DOE/EIS-0046-D. vol. 1. 
102. U.S. Department of Energy. Technology for commercial radioactive waste management. Washington, DC: U.S. DOE, Office of Nuclear Waste

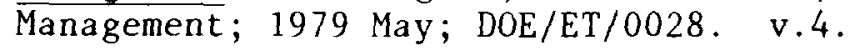

103. U.S. Department of Energy. Waste isolation pilot plant, draft environmental impact statement. Washington, DC: U.S. DOE; 1979 April; DOE/EIS-0026-D. 2v.

104. U.S. Department of Energy; U.S. Geological Survey. Earth science technical plan for mined geological disposal of radioactive waste. Washington, DC: U.S. DOE; 1979 January; TID-29018 (draft). 151 p.

105. U.S. Energy Research and Development Administration. Alternatives for managing wastes from reactors and post-fission operations in the LWR fuel cycle. Washington, DC: U.S. ERDA; 1976 May; ERDA-76-43-v. 4, 5 .

106. U.S. Energy Research and Development Administration. Management of intermediate level radioactive waste: Oak Ridge National Laboratory, Oak Ridge, Tennessee final environmental impact statement. Washington, DC: U.S. ERDA; 1977 Sept.; ERDA-1553.

107. U.S. Environmental Protection Agency. State of geological knowledge regarding potential transport of high-level radioactive waste from deep continental repositories: report of an ad hoc panel of earth scientists. Washington, DC: U.S. EPA; 1978; EPA/520/4-78-004. 53 p.

108. U.S. Nuclear Regulatory Commission. The Nuclear Regulatory Commission low-level radioactive waste management program. Washington, DC: U.S. NRC; 1977 Oct.; NUREG-0240. 29 p.

109. Venet, P.; Loggia, E. D.; Falke, W.; Haijtink, B.; Masure, P. L. Les Actions de recherche et de developpement des communautes Europeennes en matiere d'evacuation des dechets radioactifa en formations geologiques. Colloque International sur 1'evacuation des dechets radioactifs dans le sol; 1979 July 2-6; IAEA-SM-243/128. 1 p.

110. Vivian, G. A.; Olden, L. R. ; Stewart, W. B.; Carter, T. J. Reactor waste management in Ontario Hydro. Toronto, Ontario: Ontario Hydro. Presented at CNA Symposium: the management of radioactive wastes in Canada; 1979 April 10-11; Toronto, Ontario.

111. Wacks, M. E. Alternatives to shallow land burial for the disposal of low-level wastes: quarterly report June-Sept. 1978. Tucson, AZ: University of Arizona (Los Alamos Scientific Laboratory); 1978.89 p.

112. Wacks, M. E. Alternatives to shallow land burial for the disposal of low-level wastes: quarterly report Sept. 1978-Jan 1979. Tucson, AZ: University of Arizona (Los Alamos Scientific Laboratory); 1979; 113 p.

113. Wacks, M. E. Alternatives to shallow land burial for the disposal of low-level wastes: quarterly report Jan.-Mar. 1979. Tucson, AZ: University of Arizona (Los Alamos Scientific Laboratory); 1979; 135 p. 
114. Weeren, H. O. Waste disposal by shale fracturing at ORNL. Oak Ridge, TN: Oak Ridge National Laboratory. Presented at International symposium on the underground disposal of radioactive wastes; 1979 July 2-6; Otaniemi, Finland; IAEA-SM-243/42. 21 p.

115. Western, A. W.; Hall, D. H.; Coogan, J. S. Deepwell disposal of transuranic contaminated liquid waste at the Nevada test site. Post, R. G., ed. Proceedings of the symposium on waste management; 1976 0ct. 3-6; Tucson, AZ: 188-199; CONF-761020.

116. Wheeler, M. L.; Smith, W. J. Considerations for the long term: perpetual is not forever. Los Alamos, NM: Los Alamos Scientific Laboratory; 1977; LA-UR 77-640. 28 p.

117. Wheeler, M. L.; Smith, W. J.; Warren, J. L.; Whitey, W. J. Burial grounds. Presented at International symposium on the management of wastes from the LWR fuel cycle; 1976 July 11-16; Denver, C0; 329-339.

118. Winograd, I. J. Radioactive waste storage in the arid zone. EOS transactions of the American Geophysical Union $55: 884-894 ; 1974$.

119. Wivstad, I. Swedish utilities design "completely safe" disposal route. Nuclear Engineering International 23:45-48; $1978 \mathrm{Jan}$.

120. Zeller, E. J.; Angino, E. E.; Saunders, D. F. Antarctica, a potential disposal site for the world's high-level radioactive waste. Modern Geology. London: Gordon and Breach Science Publishers Ltd.; 1976; $6: 31-36$. 
INTE RNAL DISTRIBUTION

$\begin{aligned} \text { 1. } & \text { S. I. Auerbach } \\ 2 . & \text { R. E. Blanco } \\ \text { 3. } & \text { R. O. Chester } \\ \text { 4. } & \text { J. H. Coobs } \\ \text { 5. } & \text { N. H. Cutshall } \\ 6 . & \text { E. J. Frederick } \\ \text { 7. } & \text { D. E. Ferguson } \\ 8 . & \text { R. B. Fitts } \\ 9 . & \text { C. A. Little } \\ 10 . & \text { T. F. Lomenick } \\ 11 . & \text { A. L. Lotts } \\ 12-13 . & \text { R. S. Lowrie }\end{aligned}$

1. S. I. Auerbach

2. R. E. Blanco

3. R. 0. Chester

J. H. Coobs

6. E. J. Frederick

8. R. B. Fitts

9. C. A. Little

10. T. F. Lomenick

12-13. R. S. Lowrie
14. J. G. Moore

15. M. S. Moran

16. K. J. Notz

17. R. A. Robins on

18. T. Tamura

19. D. B. Trauger

20. J. E. Vath

21. N. D. Vaugh an

22-25. Laboratory Records

26. Laboratory Records - RC

27. Patent office

EXTERNAL DISTRIBUTION

28. L. Andrews, Chem Nuclear, P. O. Box 1866, Bellevue, WA 98009

29. E. L. Albenesius, Savannah River Laboratory, Aiken, SC 29801

30. T. Bergstrom, University of Michigan, Ann Arbor, MI 48109

31. L. Bradley, 2726 Country Club Drive, Olympia, WA 98502

32. R. L. Brodzinski, Battelle Northwest, 329 Bldg., 300 Area, Richland, WA 99352

33. R. Broseus, National Institute of Health, 9000 Rockville Pike, Bethesda, MD 20205

34. H. Brown, National Governors Association, 444 North Capital, Washington, DC 20555

35. P. Colombo, Brookhaven National Laboratory, Bldg. 830, Upton, NY 11973

36. P. Costello, Office of the Governor, Statehouse, Boise, ID 83702

37. T. Deboer, Empire State Plaza, Albany, NY 12223

38. J. L. Deichman, Rockwell Hanford Operation, 2750 E. Bldg., 200 E. Area, P. O. Box 800, Richland, WA 99352

39. W. Dornseife, Pennsylvania Bureau of Radiation Protection, P. O. Box 2063, Harrisburg, PA 17120

40. L. Dressen, Division of Waste Products, B 107, Washington, DC 20545

41. J. P. Duguid, Batte1le Project Management Division, 505 King Ave., Columbus, OH 43201

42. L. Franks, Bureau of Consumer Health Protection, 505 King Street, Carson City, NV 89701

43. E. Fray, EG\&G Idaho, P. O. Box 1625, Idaho Fa11s, ID 83401

44. G. Frieling, Wiscons in Electric Power Co., Milwaukee, WI 53201

45. R. H. Galbraith, 322 N. Lauderdale, Memphis, TN 38101 
46. P. J. Gillis, Stone \& Webster, P. O. Box 2325, Boston, MA 02107

47. E. Held, Office of Nuclear Regulatory Research, Mail Stop 1130-SS, Washington, DC 20555

48. D. Jacobs, Evaluation Research Corporation, Oak Ridge, TN 37830

49. J. L. Johnson, Los Alamos Scientific Laboratory, P. 0. Box 1663, Los Alamos, NM 87545

50-59. D. E. Large, Oak Ridge Operations, DOE, Oak Ridge, TN 37830

60. W. W. Larson, 81 Highland Circle, Wayland, MA 01788

61. D. Lavine, Deadhill Road, Durham, CT 06422

62. J. A. Lenhard, Oak Ridge Operations, DOE, Oak Ridge, TN 37830

63-82. G. B. Levin, EG\&G Idaho, P. O. Box 1625, Idaho Falls, ID 83401

83. T. McLaughlin, EPA, 401 M Street, SW, Washington, DC 20460

84. G. L. Meyer, EPA, 401 M Street, SW, Washington, DC 20460

85. G. Oerte1, Director, Division of Waste Products, Office of Waste Management, DOE, Washington, DC 20545

86. J. Peel, Idaho Operations, DOE, 550 Second Street, Idaho Falls, ID 83401

87. R. W. Peterson, ONWI, Batte1le Columbus Laboratory, 505 King Ave., Columbus, $\mathrm{OH} 43201$

88. S. J. Phillips, Pacific Northwest Laboratory, Rich1and, WA 99352

89. R. Pope, Sandia Laboratories, P. O. Box 5800, Albuquerque, NM 87185

90. P. Psomas, Division of Waste Management, NRC, Washington, DC 20555

91. R. Raw1, Department of Transportation, Washington, DC 20460

92. J. R. Robertson, USGS, National Center MS 410, Reston, VA 22092

93. E. M. Romney, UCLA, 900 Veteran Ave., Los Angeles, CA 90024

94. H. Shealey, Bureau of Radiological Health, 2600 Bull Street, Columbia, SC 29201

95. D. Smith, Division of Waste Management, NRC, Washington, DC 20555

96. J. G. Steger, Los Alamos Scientific Laboratory, P. 0. Box 1663, Los Alamos, NM 87545

97. J. Watson, University of North Carolina, Chape1 Hi11, NC 27514

98. J. B. Whitsett, Idaho Operations, DOE, 550 Second Street, Idaho Falls, ID 83401

99. T. Wolff, Environmental Improvement Division, P. 0. Box 968, Santa Fe, NM 97503

100. G. Yuan, Natural Resources Defense Council, 25 Kearney, San Francisco, CA 94108

101-127. Technica1 Information Center, DOE, Oak Ridge, TN 37830 